\title{
Lead-Lag Relationships in International Stock Markets Revisited: Are They Exploitable?
}

\author{
Andreas Gruener ${ }^{1}$ \& Christian Finke ${ }^{1}$ \\ ${ }^{1}$ School of Finance, University of St. Gallen, Guisanstrasse 1a, 9010 St. Gallen, Switzerland \\ Correspondence: Prof. Andreas Gruener, School of Finance, University of St. Gallen, Guisanstrasse 1a, 9010 St. \\ Gallen, Switzerland. Tel: 41-71-224-2679.
}

Received: October 22, 2017

Accepted: November 14, 2017

Online Published: November 30, 2017

doi:10.5430/ijfr.v9n1p8

URL: https://doi.org/10.5430/ijfr.v9n1p8

\begin{abstract}
This paper re-examines empirical lead-lag relationships in stock portfolios sorted by size, analyst coverage and institutional ownership across seven major developed markets. We find that lead-lag relationships continue to exist in a majority of countries. A simple trading strategy that exploits the return predictability based on lead-lag relationships yields significant abnormal returns in several markets. However, the abnormal returns quickly decline when transaction costs are introduced and become insignificant for one-way transaction costs of more than 40 basis points. Thus, lead-lag relationships are probably not exploitable in practice and will continue to exist in the future.
\end{abstract}

Keywords: lead-lag relationships, Granger-causality, transaction costs

JEL Classification Numbers: G12, G14, G15

\section{Introduction}

In their seminal work, Lo and MacKinlay (1990) find significant lead-lag relationships in market capitalization ranked U.S. equity portfolios. They show that the returns of large stocks lead the returns of small stocks, but not vice versa. Subsequent empirical studies document that this kind of lead-lag relationship is not only related to firm size but also to other firm characteristics, such as analyst coverage (Brennan, Chordia and Swaminathan (1993)), the share of institutional ownership in a firm (Bradrinath, Kale and Noe (1995)) or trading volume (Chordia and Swaminathan (2000)).

More than 20 years have passed since the first articles on lead-lag relationships in equity returns have been published in the academic literature at the beginning of the 1990s. The first contribution of this paper is to re-examine the empirical results of Lo and MacKinlay (1990), Brennan, Chordia and Swaminathan (1993) and Bradrinath, Kale and Noe (1995). The main question is whether lead-lag effects still persist after their discovery in the early 1990s or if the effects have been arbitraged away by rational investors. This research question is closely related to a recent literature that re-examines the magnitude of asset pricing anomalies after their discovery (McLean and Pontiff (2015), Tse (2015)). (Note 1) However, none of these studies investigate time-series predictability due to lead-lag relationships. We attempt to fill this gap and examine whether lead-lag relationships in the returns of portfolios sorted by size, analyst coverage and institutional ownership still exist in the United States and in six other developed markets (G7 countries). The initial articles of Lo and MacKinlay (1990), Brennan, Chordia, and Swaminathan (1993) and Bradrinath, Kale, and Noe (1995) exclusively focus on the U.S. stock market. However, studying foreign markets provides important out-of-sample evidence and helps to guard against spurious results due to data mining. We find that lead-lag effects still exist in a majority of countries. Hence, the effects have not been arbitraged away in recent years. The empirical results are remarkably stable in various robustness checks.

Having established that lead-lag relationships continue to exist, our second contribution is the examination of out-of-sample stock return predictability due to the lead-lag effect. Previous studies are only based on in-sample tests. However, the empirical return predictability literature has shifted its focus in recent years from in-sample tests to out-of-sample tests (e.g. Goyal and Welch (2008), Campbell and Thompson (2008), Rapach, Strauss and Zhou (2013)). We find that lead-lag relationships are robust in out-of-sample tests and could be potentially beneficial for a real-world investor, who attempts to profit from them. 
Based on the positive in-sample and out-of-sample results, our third contribution is to investigate if a real world investor could exploit the time-series return predictability due to lead-lag effects. Surprisingly, this question has received very little attention in the academic literature. To our best knowledge, Knez and Ready (1996) is the only existing research in this direction. However, they use a different methodology, a very short sample period and only study U.S. stocks. Furthermore, Knez and Ready (1996) only evaluate their strategy in terms of raw returns whereas we investigate risk-adjusted returns. Knez and Ready (1996) find that transactions costs are probably too large in order to exploit lead-lag effects.

We develop a simple trading strategy and find that this strategy is able to generate significant abnormal returns according to the Carhart (1997) four-factor model. However, the strategy requires frequent trading and the abnormal returns quickly decline with transaction costs. The abnormal returns in all countries become insignificant for one-way transaction costs of more than 40 basis points. Due to the liquidity issues related to the trading of stocks for which lead-lag effects are most pronounced (i.e. small stocks with low analyst coverage, low institutional ownership and low turnover), these results suggest that trading on lead-lag effects is probably not profitable in practice, which explains why the effect has not arbitraged away even though investors have known about the effect for more than twenty years. Our findings are consistent with the results in Mech (1993) and Knez and Ready (1996), who also argue that transaction costs are the main explanation for the existence of lead-lag relationships.

The particular causes of the empirically observed lead-lag relationships are still subject to an ongoing debate. Lo and MacKinlay (1990) and Boudoukh, Richardson and Whitelaw (1994) raise concerns about measurement errors in return data due to non-synchronous trading of small and large stocks. As small stocks generally trade less frequently than large stocks, their prices naturally incorporate new information at a slower rate compared to large stocks. However, the theoretical and empirical results in Lo and MacKinlay (1990), Boudoukh, Richardson and Whitelaw (1994), Mech (1993), McQueen, Pinegar and Thorley (1996), Hou and Moskowitz (2005) and Hou (2007) show that non-synchronous trading can only partially explain the lead-lag effect between large and small stocks.

Another possible explanation for lead-lag effects in stock returns suggested by (Conrad and Kaul (1988), Conrad and Kaul (1989)) are time-varying risk premia. However, several theoretical and empirical arguments cast doubt on this explanation. According to economic theory, expected returns vary slowly over the business cycle (e.g. Fama and French, 1989; Campbell and Cochrane 1999; Cochrane, 2005) and not over the daily or weekly horizon, at which lead-lag relationships are most pronounced. Moreover, investors would frequently have to accept negative risk premia if cross-serial correlation would capture time-varying expected returns. Furthermore, McQueen, Pinegar and Thorley (1996) control for variables related to time variation in expected returns and do not find that these variables capture the lead-lag effect.

A majority of studies attribute the empirically observed lead-lag effects to the gradual diffusion of value-relevant information in the stock market. (Note 2) The overall theme of this literature is that common information is first incorporated into stocks that are less affected by market frictions and then gradually diffuses into stocks affected by greater frictions. This explanation is consistent with a variety of market frictions and imperfections such as transaction costs (Mech (1993), Knez and Ready (1996)), limited investor attention (Huberman and Regev (2001), Cohen and Frazzini (2008)), the costs of information acquisition and processing (Grossman and Stiglitz (1980), Hong and Stein (2007)), institutional and legal restrictions (Merton (1987), Badrinath, Kale and Noe (1995)) and short sale constraints (Diamond and Verrechia (1987), Saffi and Sigurdsson (2010)). Hence, sorting stocks on variables such as size, analyst coverage, institutional ownership or turnover can be interpreted as cross-sectional sorts on the severity of information frictions affecting a stock.

We find that lead-lag relationships have not been arbitraged away in recent years and that the abnormal returns generated by the return predictability with a simply trading strategy quickly decrease with transaction costs. These results support the argument that transaction costs are the main factor for the continued existence of lead-lag effects.

Several theoretical models have been developed with respect to the gradual diffusion of new information across financial markets. Grossmann and Stiglitz (1980) emphasize the cost of information gathering and processing which prevents markets from being fully efficient. Merton (1987) develops a theoretical model under the assumption that investor attention is segmented across stocks due to institutional restrictions and information costs, which results in limited risk sharing. Hong and Stein (1999) and Hong, Torous and Valkanov (2007) develop theoretical asset pricing models in which investors are either unable to extract information from prices or investors can only process information from the stock market segment which they specialize in, resulting in cross-predictability of returns. Hong, Torous and Valkanov (2007) argue that cross-return-predictability effects due to investor inattention may even persist in the presence of limits to arbitrage (Shleifer and Vishny (1997)). 
This paper is organized follows: section 2 describes data and presents summary statistics. Section 3 conducts in-sample Granger-causality tests of lead-lag relationships according to firm size, analyst coverage and institutional ownership across seven stock markets. Section 4 performs out-of-sample return predictability tests. Section 5 investigates the profitability of a simple trading strategy that is designed to exploit the time-series predictability. Finally, section 6 concludes.

\section{Data}

We obtain individual stock data for all countries in the sample from Thomson Reuters Datastream (TRD). The sample covers seven major advanced economies (G7 countries): Canada, France, Germany, Italy, Japan, the United Kingdom and the United States. We restrict our sample to these countries due to their highly developed financial markets and because these countries provide a sufficiently large number of stocks to create well-diversified portfolios. Our sample period covers the 22 years from 01/1990 to 12/2011, which yields total of 1148 weekly (264 monthly) return observation. (Note 3) The empirical tests in this paper focus on weekly and monthly returns. We do not use daily returns, which are generally more contaminated by biases due to non-synchronous trading and market micro structure effects such as bid-ask bounce. We calculate weekly returns from Wednesday close to Wednesday close. National 3 month T-bill rates for all individual countries are obtained from the Global Financial Database (GFD) and serve as a proxy for local risk-free rates. Finally, we obtain data on analyst coverage from Thomson Reuters I/B/E/S and institutional ownership data is from the FactSet ownership database (LionShares). Institutional ownership is the percentage of shares outstanding held by institutional investors as in Badrinath, Kale and Noe (1995). The institutional ownership sample starts at the beginning of 2000 because of limited data availability before this date, whereas firm size and analyst coverage is available from 1990 onwards.

We put particular emphasize on the construction of our international dataset from TRD by using a structured procedure that includes multiple screens and quality checks. (Note 4) The data construction process follows three steps. In the first step, we use multiple constituent lists maintained by TRD and Worldscope (Note 5) as well as the TRD criteria search tool to find all stocks located in each country in our sample. (Note 6) We include both active and dead firms in our sample to avoid a survivorship bias. (Note 7)

In the second step, all securities in the sample are screened by the TRD datatypes TYPE, MAYOR, GEOGN and EXMNEM. The datatype TYPE="EQ" classifies an instrument as equity. MAJOR="Y" identifies the major share if a company has issued multiple equity classes. We require all firms to be located (datatype GEOGN) and listed on a regular exchange (datatype EXMNEM) in the respective country in order to exclude cross-listings and to drop all firms which are traded over-the-counter. To exclude all instruments which are not common equity (e.g. ADRs, REITs, preferred stock, investment trusts), we use a text search algorithm to search the name of each security for labels indicating that the security is not common equity, e.g. "PREF.", "ADR" and "REIT". (Note 8)

In the third step, we utilize several time-series screens to clean the data and to detect potential errors in the total return series of individual firms. When a firm stops trading, TRD repeats the last reported value for each datatype. Following Ince and Porter (2006), we handle this issue by setting to missing observations with a zero return, starting from the end of the sample. We also set all returns to missing that are affected by an extreme return reversal over two consecutive periods and returns larger than $800 \%$. (Note 9)

Table 1 provides summary statistics for our final sample. The number of available firms varies considerably across countries from 508 firms in Italy to 10129 firms in the United States. The minimum number of firms during the entire sample period is 175 (in Italy). We also find that size is positively correlated with analyst coverage and institutional ownership, which is in line with previous results in Bushan (1989) and Badrinath, Kale and Noe (1995). The correlation between firm size an analyst coverage is 0.48 on average, whereas the average correlation between size and institutional ownership is only 0.20 . Hence, portfolio sorts on size, analyst coverage and institutional ownership are not independent. To control for this dependence between size and analyst (institutional ownership) we utilize a double-sorting procedure as in Hou (2007), which is described below.

\section{Table 1. Summary statistics}

This table presents summary statistics for the final sample of international stocks obtained from Thomson Reuters Datastream. The data is cleaned and screened for potential errors as described in the text. The sample period is from $01 / 1990$ to $12 / 2011$. No. of firms is the total number of individual stocks in each country. Average no. of firms is the weekly average of available stocks. Min no. of firms is the minimum of available stocks per week. Firm-week observations is the total amount of weekly observations. Mean return is the annualized mean of the value weighted 
market return. Std. dev. return is the annualized standard deviation of the value weighted market return. Mean firm size is the average market capitalization denoted in U.S. Dollar. Mean analyst coverage is the mean of the number of analysts following a firm. Mean ownership is the mean share of institutional ownership in the firm. Ownership data is available from 2000 - 2011. Correlation size and analyst coverage is the correlation between market capitalization and analyst coverage. Correlation size and ownership is the correlation between market capitalization and institutional ownership.

\begin{tabular}{|c|c|c|c|c|c|c|c|c|c|c|c|}
\hline & $\begin{array}{l}\text { Total no. } \\
\text { of firms }\end{array}$ & $\begin{array}{l}\text { Mean no. } \\
\text { of firms }\end{array}$ & $\begin{array}{l}\text { Min no. } \\
\text { of firms }\end{array}$ & $\begin{array}{c}\text { Firm-week } \\
\text { obs }\end{array}$ & Mean return & $\begin{array}{c}\text { Std. dev. } \\
\text { return }\end{array}$ & $\begin{array}{c}\text { Mean size } \\
\text { (Mio. } \\
\text { USD) }\end{array}$ & $\begin{array}{c}\text { Mean analyst } \\
\text { coverage }\end{array}$ & $\begin{array}{c}\text { Mean } \\
\text { ownership }\end{array}$ & $\begin{array}{c}\text { Corr size } \& \\
\text { analyst }\end{array}$ & $\begin{array}{r}\text { Corr size \& } \\
\text { ownership }\end{array}$ \\
\hline Canada & 5751 & 2414 & 1398 & $2,773,033$ & $10.00 \%$ & $14.24 \%$ & 175.57 & 3.99 & $1.63 \%$ & 0.42 & 0.26 \\
\hline France & 1814 & 732 & 552 & 840,621 & $7.33 \%$ & $17.60 \%$ & 948.86 & 5.79 & $1.46 \%$ & 0.48 & 0.25 \\
\hline Germany & 1628 & 758 & 420 & 873,262 & $6.26 \%$ & $18.36 \%$ & 777.29 & 5.49 & $1.83 \%$ & 0.54 & 0.29 \\
\hline Italy & 508 & 230 & 175 & 263,822 & $5.86 \%$ & $21.75 \%$ & 1212.56 & 6.33 & $1.60 \%$ & 0.59 & 0.25 \\
\hline Japan & 7042 & 5032 & 3610 & $5,777,714$ & $-2.51 \%$ & $19.57 \%$ & 1156.21 & 3.32 & $2.47 \%$ & 0.47 & 0.24 \\
\hline $\begin{array}{l}\text { United } \\
\text { Kingdom }\end{array}$ & 4015 & 1449 & 857 & $1,663,938$ & $8.92 \%$ & $14.66 \%$ & 744.42 & 4.14 & $2.75 \%$ & 0.46 & 0.12 \\
\hline $\begin{array}{l}\text { United } \\
\text { States }\end{array}$ & 10129 & 4349 & 3463 & $4,994,088$ & $10.09 \%$ & $15.65 \%$ & 1386.06 & 6.65 & $5.79 \%$ & 0.41 & 0.01 \\
\hline
\end{tabular}

\section{In-sample Granger-causality Tests}

\subsection{Baseline Specification}

The standard procedure to analyze lead-lag relationships in equity returns is to sort all stocks into portfolios based on a certain variable and to perform Granger-causality tests with the extreme portfolios. (Note 10) In this paper we focus on lead-lag relationships with respect to size in terms of market capitalization (Lo and MacKinlay (1990)), equity analyst coverage (Brennan, Chordia and Swaminathan (1993)), and the share of institutional ownership (Bradrinath, Kale and Noe (1995)). We sort firms according to each of these variables into three portfolios: low 30\%, mid $40 \%$ and high $30 \%$.(Note 11 )

We utilize both equally and value weighted portfolio returns as each weighting scheme has its advantages and disadvantages. Value weighted portfolios are tilted towards larger and more liquid stocks. Furthermore, Asparouhova, Bessembinder and Kalcheva (2013) show that weighting returns by prior-period market capitalization mitigates the bias in stock returns caused by noise in the price data, e.g. due to non-synchronous trading and microstructure frictions. (Note 12) On the other hand, value weighted returns can be dominated by a few outliers with large market capitalization and largely ignore the information contained in prices of small firms. We decide to use both weighting schemes for robustness.

Because size is positively correlated with both analyst coverage and institutional ownership (as shown in table 1) we apply a two-way sorting procedure following Hou (2007). Specifically, we first sort all firms based on market capitalization into five quintile portfolios so that firm size is approximately constant in each portfolio. We then subdivide each of the five portfolios again based analyst coverage (institutional ownership) into 3 portfolios (low $30 \%$, mid $40 \%$, high $30 \%$ ) for a total of fifteen portfolios. The firms in the analyst coverage (institutional ownership) portfolios are then re-combined across all five size portfolios. This procedure yields three analyst coverage (institutional ownership) portfolios with approximately the same average firm size in each portfolio.

Following the portfolio formation process, we estimate bivariate vector autoregressions (VAR) and perform Granger-causality test on the cross-autoregressive coefficients. Boudoukh, Richardson and Whitelaw (1994) point out that it is important to control for own autocorrelation when testing for lead-lag relationships between high and low attention firms, which the VAR framework explicitly accounts for.

Let $R_{i, t}^{L}$ and $R_{i, t}^{H}$ denote the excess returns on the portfolios with the lowest and highest information frictions in country i, respectively. All returns are denominated in national currency and excess returns are calculated using the local risk-free rate. We regress the returns of the low (high) frictions portfolio on lagged returns of the high (low) friction portfolio and its own lags

$$
\begin{aligned}
& R_{i, t}^{H}=a_{0, i}+\sum_{k=1}^{K} a_{k, i} R_{i, t-k}^{H}+\sum_{k=1}^{K} b_{k, i} R_{i, t-k}^{L}+u_{i, t}, \\
& R_{i, t}^{L}=c_{0, i}+\sum_{k=1}^{K} c_{k, i} R_{i, t-k}^{H}+\sum_{k=1}^{K} d_{k, i} R_{i, t-k}^{L}+v_{i, t} .
\end{aligned}
$$


We set the number of lags $\mathrm{K}$ to 4 in the VAR for weekly returns. The coefficients of primary interest are the cross-autoregressive terms $b_{k, i}\left(c_{k, i}\right)$, which measure if the returns on low friction stocks are able to predict the returns on high friction stocks and vice versa. The bivariate VAR in (1) and (2) can be estimated equation by equation using ordinary least squares. Inference is based on robust Newey and West (1987) standard errors to account for autocorrelation and heteroskedasticity in the return data. (Note 13) Granger-causality is established by an F-test for testing the null hypothesis that the autoregressive terms in (1) and (2) are jointly zero, i.e. $b_{1, i}=\cdots=$ $b_{K, i}=0\left(c_{1, i}=\cdots=c_{K, i}=0\right)$. According to the empirical results in previous studies, we expect to find that $R_{i, t}^{L}$ Granger-causes $R_{i, t}^{H}$ but not vice versa.

We also estimate a pooled version of the bivariate VAR (1) and (2), where we pool the observations from all countries in our sample. Pooling observations from multiple countries has been advocated in the literature on international return predictability to improve statistical power and forecast performance (Ang and Bekaert (2007), Hjalmarsson (2010), Rapach, Strauss, and Zhou (2013)). (Note 14) The pooled estimates measure the average lead-lag relationship across all countries. Specifically, we stack $R_{i, t}^{L}\left(R_{i, t}^{H}\right)$ of all seven countries into a system, imposing the restriction that the autoregressive and cross-autoregressive terms in (1) and (2) are identical across countries, i.e. $a_{k, i}=\bar{a}_{k}, b_{k, i}=\bar{b}_{k}, c_{k, i}=\bar{c}_{k}$ and $d_{k, i}=\bar{d}_{k}$. However, the intercepts $a_{0, i}$ and $c_{0, i}$ differ across countries.

Table 2 reports the results for the bivariate VAR in (1) and (2) estimated with high and low information friction portfolios as measured by size, analyst coverage and institutional ownership for the seven countries and the pooled sample. To preserve space, we only report the results of the cross-autoregressive coefficients $b_{k, i}\left(c_{k, i}\right)$ which are our primary interest. The table reports the estimation results for the individual coefficients and the Granger-causality tests. The estimates of the individual coefficients give an insight into how long the information contained in the prices of low friction firms take to diffuse into the prices of high friction firms.

Table 2. In-sample Granger-causality tests

This table reports the coefficient estimates and significance levels for the bivariate vector autoregressions with weekly stocks returns sorted by market capitalization, analyst coverage and institutional ownership. The sample period is $01 / 1990$ - 12/2011for stocks sorted by market capitalization and analyst coverage and 01/2000 - 12/2011 for stocks sorted by institutional ownership. The portfolios sorted by analyst coverage and institutional ownership are orthogonalized with respect to size using the double sorting procedure described in the text. Pooled denotes estimates obtained by pooling the observations from all countries. Let $R_{i, t}^{H}\left(R_{i, t}^{L}\right)$ denote the return on stocks with high (low) information frictions as indicated by low (high) market capitalization, low (high) analyst coverage or low (high) institutional ownership in country $i$, respectively. The bivariate vector autoregression is given by

$$
\begin{aligned}
& R_{i, t}^{H}=a_{0, i}+\sum_{k=1}^{K} a_{k, i} R_{i, t-k}^{H}+\sum_{k=1}^{K} b_{k, i} R_{i, t-k}^{L}+u_{i, t}, \\
& R_{i, t}^{L}=c_{0, i}+\sum_{k=1}^{K} c_{k, i} R_{i, t-k}^{H}+\sum_{k=1}^{K} d_{k, i} R_{i, t-k}^{L}+v_{i, t} .
\end{aligned}
$$

The table reports the coefficient estimates and significance levels of the lead-lag coefficients $\mathrm{b}(\mathrm{k})$ and $\mathrm{c}(\mathrm{k})$. The Granger-causality test tests the null hypothesis $b_{1, i}=\cdots=b_{K, i}=0\left(c_{1, i}=\cdots=c_{K, i}=0\right)$. Standard errors are computed using the Newey and West (1987) procedure. $\mathrm{R}^{2}$ is the adjusted r-squared. $\mathrm{N}$ is the number of observations. $*, * *$ and $* * *$ denote statistical significance at the $10 \%, 5 \%$, and $1 \%$ level, respectively. 
Panel A: Size sorted portfolios

Equally weighted

Value weighted

\begin{tabular}{|c|c|c|c|c|c|c|c|c|c|c|c|c|c|c|c|c|}
\hline \multirow{2}{*}{\multicolumn{17}{|c|}{ Panel A: Size sorted porffolios }} \\
\hline & & & & & & & & & & & & & & & & \\
\hline & $\mathrm{CAN}$ & FRA & GER & ITA & JPN & $\mathrm{UK}$ & US & Pooled & $\mathrm{CAN}$ & FRA & GER & ITA & JPN & UK & US & Pooled \\
\hline & \multicolumn{16}{|c|}{ VAR results: small firms on large firms } \\
\hline $\mathrm{b}(1)$ & $0.19^{* * *}$ & $0.16^{* * *}$ & 0.06 & $0.14^{* * *}$ & $0.20^{* * *}$ & $0.23^{* * *}$ & $0.17^{* * *}$ & $0.13^{* * *}$ & $0.17^{* * *}$ & $0.11^{* * *}$ & 0.00 & $0.12^{* * *}$ & $0.11^{* *}$ & $0.14^{* *}$ & $0.11^{*}$ & $0.08^{* * *}$ \\
\hline$b(2)$ & 0.03 & 0.02 & 0.03 & 0.07 & -0.04 & $0.10^{* *}$ & -0.02 & 0.01 & 0.02 & 0.03 & 0.05 & 0.02 & -0.04 & $0.08^{*}$ & -0.04 & 0.01 \\
\hline$b(3)$ & 0.12 & 0.05 & 0.01 & $0.11^{* *}$ & 0.11 & -0.01 & -0.03 & 0.03 & $0.15^{*}$ & $0.06^{* *}$ & 0.04 & $0.08^{*}$ & 0.09 & 0.02 & -0.02 & $0.05^{* *}$ \\
\hline$b(4)$ & $-0.28^{* * *}$ & -0.05 & -0.08 & -0.05 & 0.09 & -0.03 & -0.02 & $-0.07 * *$ & $-0.14^{* *}$ & -0.03 & -0.05 & -0.03 & 0.08 & -0.04 & -0.01 & $-0.04^{* *}$ \\
\hline $\operatorname{Sum}(b)$ & 0.06 & 0.18 & 0.02 & 0.28 & 0.36 & 0.28 & 0.10 & 0.11 & 0.21 & 0.17 & 0.04 & 0.19 & 0.24 & 0.20 & 0.04 & 0.10 \\
\hline $\begin{array}{l}\text { Granger } \\
\text { causality }\end{array}$ & $6.68^{* * *}$ & $2.82^{* *}$ & 0.84 & $3.58^{* * *}$ & $3.42^{* * *}$ & $5.21^{* * *}$ & $2.43^{* *}$ & $17.84^{* * *}$ & $6.36^{* * *}$ & $3.28^{* *}$ & 1.28 & $2.78^{* *}$ & $2.19^{*}$ & $2.21^{*}$ & 1.09 & $11.15^{* * *}$ \\
\hline $\mathrm{R}^{2}$ & 0.22 & 0.15 & 0.12 & 0.07 & 0.04 & 0.14 & 0.13 & 0.13 & 0.20 & 0.15 & 0.11 & 0.06 & 0.04 & 0.13 & 0.09 & 0.11 \\
\hline \multirow[t]{2}{*}{$\mathrm{N}$} & 1144 & 1144 & 1144 & 1144 & 1144 & 1144 & 1144 & 8008 & 1144 & 1144 & 1144 & 1144 & 1144 & 1144 & 1144 & 8008 \\
\hline & \multicolumn{16}{|c|}{ VAR results: large firms on small firms } \\
\hline$c(1)$ & 0.01 & 0.07 & 0.01 & 0.03 & 0.05 & -0.09 & -0.11 & 0.01 & 0.01 & 0.07 & 0.08 & 0.00 & 0.01 & 0.00 & -0.06 & 0.02 \\
\hline$c(2)$ & -0.04 & 0.02 & 0.01 & 0.05 & 0.04 & -0.04 & 0.10 & 0.00 & -0.03 & 0.03 & -0.04 & $0.10^{*}$ & 0.00 & -0.05 & 0.06 & -0.01 \\
\hline$c(3)$ & 0.01 & 0.06 & 0.05 & -0.04 & 0.00 & $0.11^{*}$ & 0.09 & 0.03 & -0.01 & -0.01 & 0.03 & -0.03 & 0.01 & 0.03 & 0.06 & 0.01 \\
\hline$c(4)$ & $0.06^{* *}$ & 0.08 & 0.01 & 0.06 & $-0.10^{* *}$ & 0.02 & -0.09 & 0.00 & 0.02 & 0.08 & 0.00 & 0.02 & $-0.10^{* *}$ & 0.00 & $-0.13^{* *}$ & -0.01 \\
\hline $\operatorname{Sum}(c)$ & 0.03 & 0.23 & 0.08 & 0.10 & -0.01 & 0.00 & -0.01 & 0.05 & 0.00 & 0.16 & 0.07 & 0.09 & -0.07 & -0.01 & -0.07 & 0.01 \\
\hline $\begin{array}{l}\text { Granger } \\
\text { caussality }\end{array}$ & 1.55 & $2.03^{*}$ & 0.62 & 0.55 & 1.74 & 1.52 & 1.22 & 1.42 & 0.38 & 0.94 & 0.59 & 0.94 & 1.20 & 0.36 & 1.23 & 0.75 \\
\hline $\mathrm{R}^{2}$ & 0.04 & 0.01 & 0.01 & 0.02 & 0.01 & 0.01 & 0.01 & 0.01 & 0.00 & 0.01 & 0.01 & 0.02 & 0.01 & 0.01 & 0.01 & 0.01 \\
\hline $\mathrm{N}$ & 1144 & 1144 & 1144 & 1144 & 1144 & 1144 & 1144 & 8008 & 1144 & 1144 & 1144 & 1144 & 1144 & 1144 & 1144 & 8008 \\
\hline
\end{tabular}

Panel B: Analyst sorted portfolios

Equally weighted

Value weighted

\begin{tabular}{|c|c|c|c|c|c|c|c|c|c|c|c|c|c|c|c|c|}
\hline \multirow{2}{*}{\multicolumn{17}{|c|}{ Panel A: Analvst sorted portfolios }} \\
\hline & & \multicolumn{15}{|c|}{ Panel A: Analyst sorted porffolios } \\
\hline & $\mathrm{CAN}$ & FRA & GER & ITA & JPN & UK & US & Pooled & CAN & FRA & GER & ITA & JPN & UK & US & Pooled \\
\hline & \multicolumn{16}{|c|}{ VAR results: low analyst coverage firms on high analyst coverage firms } \\
\hline$b(1)$ & $0.13^{* * *}$ & $0.12^{* * *}$ & $0.20^{* * *}$ & $0.11^{* *}$ & $0.32^{* * *}$ & $0.14^{* * *}$ & 0.09 & $0.15^{* * *}$ & $0.08^{*}$ & $0.08^{* *}$ & $0.12^{* * *}$ & 0.07 & $0.22^{* *}$ & $0.14^{* * *}$ & 0.03 & $0.08^{* * *}$ \\
\hline$b(2)$ & -0.03 & 0.02 & 0.03 & -0.01 & -0.04 & 0.07 & 0.01 & $0.03^{*}$ & -0.04 & 0.04 & $0.08^{*}$ & -0.02 & 0.00 & 0.01 & 0.04 & $0.04^{* * *}$ \\
\hline$b(3)$ & 0.03 & 0.02 & 0.05 & $0.12^{* *}$ & 0.06 & 0.05 & 0.08 & $0.07^{* * *}$ & 0.08 & 0.00 & 0.06 & $0.11^{* *}$ & 0.06 & 0.08 & 0.10 & $0.07^{* * *}$ \\
\hline$b(4)$ & -0.04 & -0.01 & -0.08 & -0.05 & 0.03 & -0.01 & -0.04 & -0.02 & -0.03 & -0.02 & -0.03 & -0.04 & 0.05 & 0.01 & -0.09 & 0.03 \\
\hline $\operatorname{Sum}(b)$ & 0.10 & 0.16 & 0.20 & 0.17 & 0.37 & 0.24 & 0.15 & 0.23 & 0.09 & 0.10 & 0.23 & 0.12 & 0.32 & 0.23 & 0.08 & 0.22 \\
\hline Granger & & & & & & & & & & & & & & & & \\
\hline causality & $3.47^{* * *}$ & $6.05^{* * *}$ & $11.42^{* * *}$ & $4.30^{* * *}$ & $3.80^{* * *}$ & $6.14^{* * *}$ & 1.36 & $28.60^{* * *}$ & $2.04^{*}$ & $3.40^{* * *}$ & $7.45^{* * *}$ & $3.40^{* * *}$ & $2.30^{*}$ & $5.05^{* * *}$ & 1.40 & $16.39^{* * *}$ \\
\hline $\mathrm{R}^{2}$ & 0.09 & 0.13 & 0.08 & 0.06 & 0.03 & 0.20 & 0.01 & 0.07 & 0.05 & 0.09 & 0.06 & 0.05 & 0.02 & 0.15 & 0.00 & 0.02 \\
\hline \multirow[t]{2}{*}{$\mathrm{N}$} & 1144 & 1144 & 1144 & 1144 & 1144 & 1144 & 1144 & 8008 & 1144 & 1144 & 1144 & 1144 & 1144 & 1144 & 1144 & 8008 \\
\hline & \multicolumn{16}{|c|}{ VAR results: low analyst coverage firms on high analyst coverage firms } \\
\hline$c(1)$ & $0.13^{* * *}$ & -0.03 & -0.20 & -0.01 & $-0.34^{* * *}$ & 0.00 & $-0.29^{*}$ & -0.02 & 0.04 & 0.00 & -0.03 & -0.03 & $-0.31^{* * *}$ & -0.06 & -0.21 & $-0.05^{* *}$ \\
\hline$c(2)$ & 0.04 & 0.03 & 0.02 & 0.07 & 0.05 & -0.04 & -0.01 & 0.01 & 0.08 & 0.00 & -0.04 & $0.15^{* *}$ & -0.02 & 0.01 & -0.04 & -0.01 \\
\hline$c(3)$ & 0.08 & 0.14 & -0.01 & -0.09 & -0.04 & -0.05 & -0.20 & 0.01 & 0.03 & 0.13 & -0.10 & -0.03 & -0.05 & 0.03 & $-0.19^{*}$ & 0.00 \\
\hline$c(4)$ & -0.02 & -0.03 & 0.04 & -0.01 & -0.08 & 0.03 & 0.03 & -0.01 & -0.06 & 0.04 & -0.07 & -0.07 & -0.10 & -0.08 & 0.08 & $-0.05^{* *}$ \\
\hline $\begin{array}{l}\text { Sum(c) } \\
\text { Granger }\end{array}$ & 0.23 & 0.12 & -0.16 & -0.03 & -0.41 & -0.06 & -0.47 & -0.01 & 0.09 & 0.16 & -0.24 & 0.01 & -0.48 & -0.10 & -0.36 & -0.10 \\
\hline $\begin{array}{l}\text { Granger } \\
\text { causality }\end{array}$ & $2.60^{* *}$ & 1.12 & 1.57 & 0.72 & $3 \cdot 10^{* *}$ & 0.27 & $264^{* *}$ & 0.32 & 1.14 & 1.13 & 0.71 & 189 & $3.09 * *$ & 0.63 & $244^{* *}$ & $4.01^{* * *}$ \\
\hline $\mathrm{R}^{2}$ & 0.08 & 0.08 & 0.06 & 0.05 & 0.03 & 0.16 & 0.03 & 0.01 & 0.06 & 0.04 & 0.03 & 0.04 & 0.02 & 0.12 & 0.02 & 0.01 \\
\hline $\mathrm{N}$ & 1144 & 1144 & 1144 & 1144 & 1144 & 1144 & 1144 & 8008 & 1144 & 1144 & 1144 & 1144 & 1144 & 1144 & 1144 & 8008 \\
\hline
\end{tabular}


Panel C: Ownership sorted portfolios

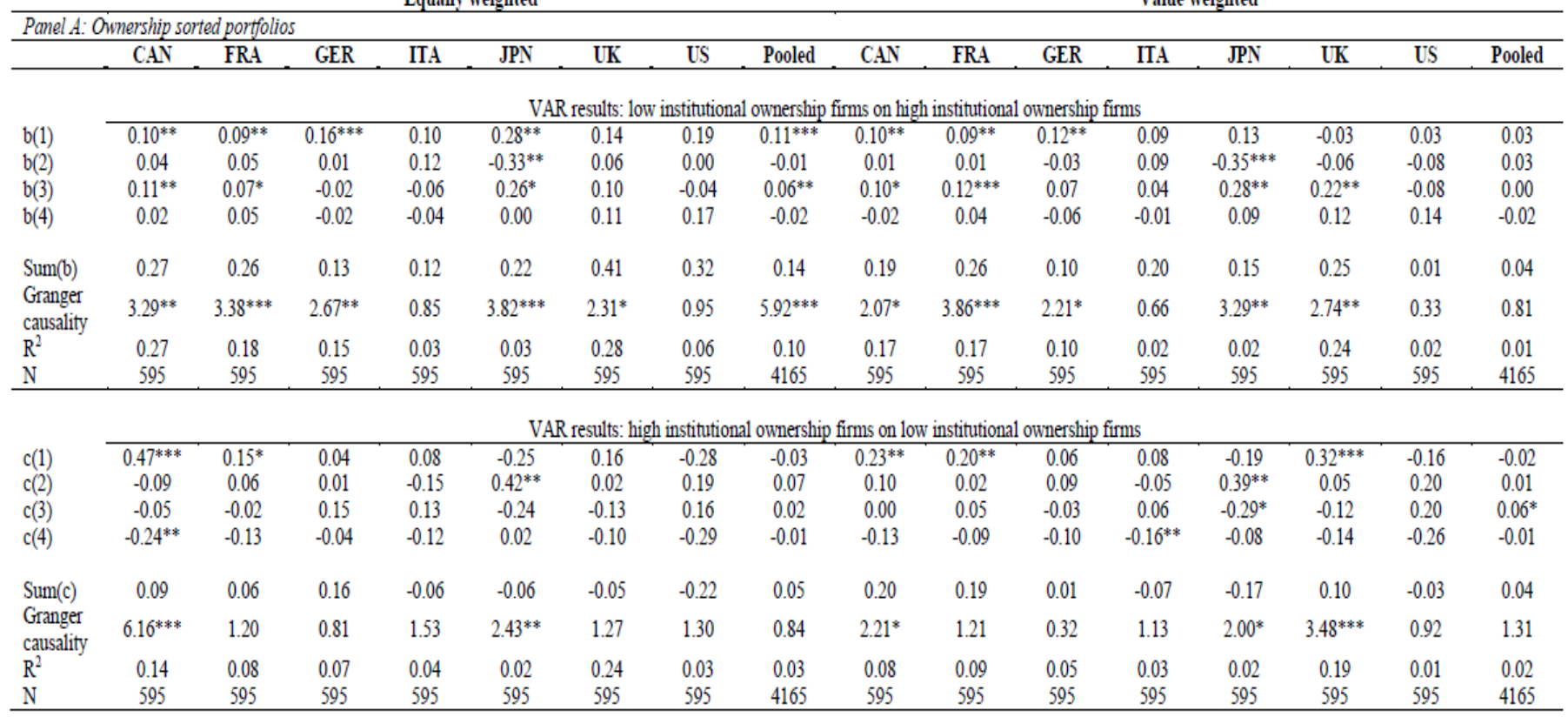

Panel A of Table 2 reports the results for lead-lag relationships across size sorted portfolios. The coefficients of determination show that the fraction of return variation explained by (1) and (2) is generally larger for the returns of small firms, indicating that the returns of small firms exhibit greater predictability. The Granger-causality test for regression equation (1) (i.e. testing the null $b_{1, i}=\cdots=b_{K, i}=0$ ) is statistically significant for 6 (5) out of 7 countries using equally (value) weighted portfolios. The first lag coefficient $\hat{b}_{1, i}$ is also positive and statistically significant 6 out of 7 countries. (Note 15) Higher order lags are mainly insignificant in individual countries and the pooled sample. Interestingly, the coefficient at lag 4 is often negative but insignificant. However, $\widehat{b_{4}}$ is significantly negative for Canada as well as the pooled sample, which suggests the existence of a slight reversion effect at lag 4. (Note 16) Turning to the estimation results for equation (2) in the VAR, which predicts the returns on large firms with lagged returns on small firms, we observe that $\hat{c}_{k, i}$ is generally insignificant across countries. Only one country, France, exhibits a significant Granger-causality test for equation (2) using equally weighted returns. However, all Granger-causality tests are insignificant using value weighted returns. Also none of the pooled estimates $\widehat{\widehat{c_{k}}}$ are statistically significant and neither are the Granger-causality tests for the pooled sample. These results confirm the previous notion that large firms predict small firms but not vice versa.

Panel B of Table 2 reports the results for lead-lag relationships across analyst-sorted portfolios, keeping size approximately fixed across portfolios. The Granger causality test is significant for 6 out of 7 portfolios. Interestingly, the Granger-causality test and individual $\hat{b}_{k, i}$ estimates are insignificant for the United States, which is in contrast to the previous results in Brennan, Chordia and Swaminathan (1993). The Granger-causality tests of the pooled samples are significant for both equally weighted and value weighted portfolios. The individual estimates for $\hat{c}_{k, i}$ are largely insignificant and close to zero on average in the pooled estimates. $\hat{c}_{1, i}$ is significantly negative for Japan and the United States. However, note that our tests measure the relative speed of price adjustment to new information between two portfolios. Brennan, Chordia and Swaminathan (1993) show that, when the returns of stocks with faster price adjustment are regressed on lagged returns of stocks with slower price adjustment, the resulting cross-coefficients can be negative. 
Finally, Panel $\mathrm{C}$ of Table 2 reports the results for lead-lag relationships across institutional ownership sorted portfolios, keeping size approximately fixed. The Granger-causality test for the joint significance of $\hat{b}_{k, i}$ is significant for 5 out of 7 countries. However, the first lag estimates $\hat{b}_{1, i}$ are only significant for 4 (2) countries using equally (value) weighted portfolios. (Note 17) In the value weighted pooled sample, none of the $\widehat{b_{k}}$ estimates is statistically significant and neither is the corresponding Granger-causality test. Hence, we find no significant lead-lag effect in the pooled sample using value weighted returns. A possible explanation for this finding is that the effect is primarily driven by small firms, which receive less weight in the value weighted portfolios.

In summary, we find that lead-lag relationships according to size and analyst coverage continue to exist in a majority of counties after their discovery in the early 1990s. The results are robust across equally weighted and value weighted portfolios. We find less robust evidence for the continued existence of lead-lag relationships according to institutional ownership. However, care must be taken in the interpretation of the results based on institutional ownership because of the limited sample period, which only starts in 2000.

\subsection{Robustness Checks}

\subsubsection{Influence of Micro Caps}

This section investigates the robustness of the empirical lead-lag effects documented in table 2 excluding micro caps. This is especially important from the perspective of a real-world investor as micro caps are particularly difficult to trade due to their small size and illiquidity. Keim (1999) discusses the problems of a mutual designed to capture stock returns in the $9^{\text {th }}$ and $10^{\text {th }}$ size deciles according to NYSE market capitalization such as high trading costs and the necessity to execute trades over several days. Keim (1999) notes that the fund often waits until firms grow into the $8^{\text {th }}$ decile of NYSE market cap and until it sells positions.

It is well-known that micro caps can have a large influence on the results in empirical asset pricing studies. Fama and French (2008) find that micro caps, which the authors define as stocks with a market capitalization below the $20^{\text {th }}$ NYSE percentile, on average account for $60 \%$ percent of the total number of stocks but only comprise $3 \%$ of total market capitalization in a sample of NYSE, NASDAQ and AMEX stocks. If lead-lag relationships only exist among the smallest and most illiquid stocks, they may be not exploitable by a real-world investor. Fama and French (2008) note that "...if the extreme returns associated with an anomaly variable are special to microcaps, they are probably not realizable because of the high costs of trading such stocks." (p. 1655).

Following the discussions in Keim (1999) and Fama and French (2008), we exclude all micro caps from our sample. As there is no universal definition for the firm size of a micro cap, we follow the definition of Fama and French (2008) and exclude all stocks with a smaller market capitalization than the $20^{\text {th }}$ NYSE percentile. (Note 18) At the beginning of our sample in 1990 the $20^{\text {th }}$ NYSE percentile corresponds to over USD 100 Mio. and at the end of our sample period in 2011 the $20^{\text {th }}$ NYSE percentile corresponds to over USD 500 Mio. This restriction reduces the number of stocks in the sample by $49 \%$. As before, we sort the remaining stocks into three portfolios based on the $(30 \%, 40 \%, 30 \%)$ and then estimate a bivariate VAR (1) and (2) and Granger-causality tests. The results are reported in Table 3.

Panel A reports the lead-lag relationship for size-sorted portfolios excluding micro caps. As expected, we find that the number of significant lead-lag relationships decreases. However, we still observe significant Granger-causality in 4 out of 7 countries using equally and value weighted returns. Interestingly, the sum of the pooled $\widehat{\widehat{b_{k}}}$ estimates is even larger compared to the base case with micro caps because the estimates for higher order lags are larger compared to the results in table 2 and significant up to lag 3.

Panel B shows that the number of significant coefficients also decreases for the portfolios sorted by analyst coverage. Only 3 countries (France, Germany and Italy) continue to display a significant lead-lag relationship according to the

Granger-causality test for the joint significance of $\hat{b}_{k, i}$. Finally, panel $\mathrm{C}$ shows that only 2 (1) countries exhibit statistically significant return predictability across equally (value) weighted ownership-sorted portfolios according to the Granger-causality test for $\hat{b}_{k, i}$.

Overall, the results in table 3 show that the number of statistically significant lead-lag relationships declines considerably when micro caps are excluded from the sample. However, a number of statistically significant predictive relationships remain, especially in portfolios based on size. On the other hand, we find only few remaining 
lead-lag relationships across portfolios sorted by analyst coverage and institutional ownership, which suggests that these effects are particularly driven by very small firms.

Table 3. In-sample Granger-causality tests: excluding micro caps

This table reports the coefficient estimates and significance levels for the bivariate vector autoregressions with weekly stocks returns sorted by market capitalization, analyst coverage and institutional ownership. The sample excludes micro caps defined as stocks below the $20 \%$ NYSE quintile according to market capitalization. The sample period is 01/1990 - 12/2011for stocks sorted by market capitalization and analyst coverage and 01/2000 - 12/2011 for stocks sorted by institutional ownership. The portfolios sorted by analyst coverage and institutional ownership are orthogonalized with respect to size as described in the text. Pooled denotes estimates obtained by pooling the observations from all countries. Let $R_{i, t}^{H}\left(R_{i, t}^{L}\right)$ denote the return on stocks with high (low) information frictions as indicated by low (high) market capitalization, low (high) analyst coverage or low (high) institutional ownership in country i, respectively. The bivariate vector autoregression is given by

$$
\begin{aligned}
& R_{i, t}^{H}=a_{0, i}+\sum_{k=1}^{K} a_{k, i} R_{i, t-k}^{H}+\sum_{k=1}^{K} b_{k, i} R_{i, t-k}^{L}+u_{i, t}, \\
& R_{i, t}^{L}=c_{0, i}+\sum_{k=1}^{K} c_{k, i} R_{i, t-k}^{H}+\sum_{k=1}^{K} d_{k, i} R_{i, t-k}^{L}+v_{i, t}^{L} .
\end{aligned}
$$

The table reports the coefficient estimates and significance levels of the lead-lag coefficients $\mathrm{b}(\mathrm{k})$ and $\mathrm{c}(\mathrm{k})$. The Granger-causality test tests the null hypothesis $b_{1, i}=\cdots=b_{K, i}=0\left(c_{1, i}=\cdots=c_{K, i}=0\right)$. Standard errors are computed using the Newey and West (1987) procedure. $\mathrm{R}^{2}$ is the adjusted $\mathrm{r}$-squared. $\mathrm{N}$ is the number of observations. $*, * *$ and $* * *$ denote statistical significance at the $10 \%, 5 \%$, and $1 \%$ level, respectively.

Panel A: Size sorted portfolios

Equally weighted

\begin{tabular}{|c|c|c|c|c|c|c|c|c|c|c|c|c|c|c|c|c|}
\hline \multirow{2}{*}{\multicolumn{17}{|c|}{ Panel A: Size sorted portfolios }} \\
\hline & & & & & & & & & & & & & & & & \\
\hline & $\mathrm{CAN}$ & FRA & GER & ITA & JPN & UK & US & Pooled & $\mathrm{CAN}$ & FRA & GER & ITA & JPN & UK & US & Pooled \\
\hline & \multicolumn{16}{|c|}{ VAR results: small firms on large firms } \\
\hline $\mathrm{b}(1)$ & $0.19^{* *}$ & $0.11^{* *}$ & 0.08 & 0.08 & 0.12 & $0.17^{* *}$ & $0.21^{*}$ & $0.12^{* * *}$ & 0.11 & $0.07^{*}$ & 0.06 & 0.07 & 0.03 & 0.11 & 0.08 & $0.07^{* * *}$ \\
\hline$b(2)$ & 0.03 & 0.05 & $0.09^{*}$ & 0.04 & 0.02 & $0.16^{* * *}$ & -0.13 & $0.06^{* * *}$ & 0.04 & $0.06^{*}$ & $0.07^{* *}$ & 0.04 & -0.01 & $0.11^{* *}$ & -0.06 & $0.05^{* * *}$ \\
\hline $\mathrm{b}(3)$ & $0.16^{* *}$ & 0.07 & 0.04 & 0.03 & 0.07 & 0.07 & 0.12 & $0.07^{* * *}$ & $0.17^{* * *}$ & $0.09^{* *}$ & 0.06 & 0.04 & 0.06 & 0.05 & 0.05 & $0.07^{* * *}$ \\
\hline$b(4)$ & -0.10 & -0.03 & 0.02 & -0.06 & 0.11 & -0.01 & 0.08 & -0.01 & -0.07 & -0.01 & -0.01 & -0.06 & 0.09 & 0.00 & 0.06 & 0.00 \\
\hline $\operatorname{Sum}(\mathrm{b})$ & 0.29 & 0.20 & 0.23 & 0.08 & 0.32 & 0.39 & 0.28 & 0.24 & 0.25 & 0.21 & 0.19 & 0.08 & 0.18 & 0.26 & 0.14 & 0.18 \\
\hline $\begin{array}{l}\text { Granger } \\
\text { causality }\end{array}$ & $4.70^{* * *}$ & $3.55^{* * *}$ & 1.75 & 1.45 & 1.75 & $5.61^{* * *}$ & $2.89 * *$ & $13.01^{* * *}$ & $4.23^{* * *}$ & $2.98^{* *}$ & $2.29^{*}$ & 1.65 & 1.20 & $3.04^{* *}$ & 0.75 & $9.34^{* * *}$ \\
\hline $\mathrm{R}^{2}$ & 0.02 & 0.06 & 0.02 & 0.04 & 0.02 & 0.07 & 0.01 & 0.03 & 0.02 & 0.05 & 0.02 & 0.04 & 0.01 & 0.06 & 0.01 & 0.03 \\
\hline $\mathrm{N}$ & 1144 & 1144 & 1144 & 1144 & 1144 & 1144 & 1144 & 8008 & 1144 & 1144 & 1144 & 1144 & 1144 & 1144 & 1144 & 8008 \\
\hline \multicolumn{17}{|c|}{ VAR results: large firms on small firms } \\
\hline$c(1)$ & -0.06 & 0.01 & -0.05 & 0.00 & -0.01 & -0.08 & -0.08 & -0.02 & -0.01 & 0.03 & 0.02 & -0.03 & -0.02 & 0.01 & -0.03 & 0.00 \\
\hline$c(2)$ & -0.02 & 0.07 & -0.04 & 0.08 & -0.05 & -0.10 & 0.10 & -0.01 & -0.02 & 0.05 & 0.02 & 0.08 & -0.06 & -0.04 & 0.02 & -0.01 \\
\hline$c(3)$ & -0.05 & -0.02 & 0.02 & 0.10 & 0.01 & 0.07 & -0.01 & 0.02 & -0.05 & -0.05 & -0.07 & 0.08 & 0.01 & 0.02 & 0.03 & 0.00 \\
\hline$c(4)$ & 0.06 & 0.02 & -0.04 & -0.06 & $-0.16^{* *}$ & 0.00 & $-0.16^{* *}$ & -0.04 & 0.04 & 0.03 & -0.02 & -0.07 & $-0.12^{*}$ & -0.05 & $-0.15^{* * *}$ & $-0.04^{*}$ \\
\hline $\operatorname{Sum}(\mathrm{c})$ & -0.06 & 0.08 & -0.11 & 0.11 & -0.21 & -0.10 & -0.14 & -0.06 & -0.05 & 0.06 & -0.07 & 0.07 & -0.19 & -0.05 & -0.13 & -0.05 \\
\hline $\begin{array}{l}\text { Granger } \\
\text { causality }\end{array}$ & 1.17 & 0.37 & 0.44 & 1.29 & $2.05^{*}$ & 1.62 & $2.44^{* *}$ & 1.44 & 0.71 & 0.47 & 0.45 & 1.47 & $2.10^{*}$ & 0.54 & $2.83^{* *}$ & 1.52 \\
\hline $\mathrm{R}^{2}$ & 0.00 & 0.01 & 0.01 & 0.02 & 0.01 & 0.01 & 0.01 & 0.01 & 0.00 & 0.02 & 0.01 & 0.02 & 0.01 & 0.01 & 0.01 & 0.01 \\
\hline $\mathrm{N}$ & 1144 & 1144 & 1144 & 1144 & 1144 & 1144 & 1144 & 8008 & 1144 & 1144 & 1144 & 1144 & 1144 & 1144 & 1144 & 8008 \\
\hline
\end{tabular}

Value weighted 
Panel B: Analyst sorted portfolios

Equally weighted

Value weighted

\begin{tabular}{|c|c|c|c|c|c|c|c|c|c|c|c|c|c|c|c|c|}
\hline \multirow{2}{*}{\multicolumn{17}{|c|}{ Panel A: Analyst sorted portfolios }} \\
\hline & & & & & & & & & & & & & & & & \\
\hline \multirow{6}{*}{$\begin{array}{l}\mathrm{b}(1) \\
\mathrm{b}(2) \\
\mathrm{b}(3) \\
\mathrm{b}(4)\end{array}$} & $\mathrm{CAN}$ & FRA & GER & IIA & JPN & UK & US & Pooled & $\mathrm{CAN}$ & FRA & GER & ITA & JPN & UK & US & Pooled \\
\hline & \multicolumn{16}{|c|}{ VAR results: low analyst coverage firms on high analyst coverage firms } \\
\hline & 0.03 & $0.09^{*}$ & 0.02 & $0.11^{* *}$ & 0.03 & 0.06 & -0.01 & $0.05^{* *}$ & 0.01 & $0.09 * *$ & 0.05 & $0.12^{* *}$ & 0.05 & 0.05 & -0.02 & $0.10^{* *}$ \\
\hline & -0.02 & 0.03 & $0.09^{* * *}$ & 0.00 & -0.02 & 0.01 & 0.05 & $0.03^{*}$ & -0.01 & 0.02 & $0.09 * * *$ & -0.02 & 0.00 & 0.01 & 0.02 & 0.00 \\
\hline & $0.08^{*}$ & 0.01 & -0.02 & $0.11^{* * *}$ & 0.06 & 0.01 & 0.07 & $0.07^{* * *}$ & $0.07^{*}$ & 0.01 & -0.03 & $0.09 * *$ & 0.03 & 0.04 & 0.06 & 0.02 \\
\hline & -0.02 & 0.00 & 0.01 & -0.06 & 0.08 & -0.04 & -0.10 & 0.01 & 0.03 & -0.01 & -0.02 & -0.06 & 0.08 & -0.04 & -0.09 & 0.01 \\
\hline \multirow{4}{*}{$\begin{array}{l}\text { Sum(b) } \\
\text { Granger } \\
\text { causality } \\
\mathrm{R}^{2} \\
\mathrm{~N}\end{array}$} & 0.07 & 0.13 & 0.10 & 0.16 & 0.14 & 0.05 & 0.01 & 0.16 & 0.10 & 0.11 & 0.08 & 0.13 & 0.17 & 0.05 & -0.04 & 0.13 \\
\hline & 1.21 & $2.46^{* *}$ & $3.34^{* * *}$ & $4.82^{* * *}$ & 0.59 & 0.74 & 1.08 & $7.97^{* * *}$ & 1.22 & $2.29^{*}$ & $4.20^{* * *}$ & $4.49^{* * *}$ & 0.66 & 0.77 & 0.72 & $12.21^{* * *}$ \\
\hline & 0.01 & 0.04 & 0.02 & 0.05 & 0.00 & 0.04 & 0.01 & 0.02 & 0.01 & 0.02 & 0.03 & 0.05 & 0.00 & 0.03 & 0.00 & 0.02 \\
\hline & 1144 & 1144 & 1144 & 1144 & 1144 & 1144 & 1144 & 8008 & 1144 & 1144 & 1144 & 1144 & 1144 & 1144 & 1144 & 8008 \\
\hline & \multicolumn{16}{|c|}{ VAR results: high analyst coverage firms on low analyst coverage firms } \\
\hline$c(1)$ & -0.01 & -0.05 & -0.06 & $-0.12^{*}$ & -0.12 & -0.13 & -0.20 & -0.02 & 0.01 & -0.08 & -0.04 & $-0.15^{* *}$ & $-0.16^{*}$ & -0.12 & -0.15 & 0.01 \\
\hline$c(2)$ & 0.01 & -0.03 & -0.10 & 0.08 & 0.03 & 0.00 & -0.07 & -0.02 & 0.02 & -0.04 & -0.10 & $0.10^{*}$ & 0.01 & -0.02 & -0.03 & -0.04 \\
\hline$c(3)$ & -0.07 & 0.02 & 0.13 & -0.01 & -0.02 & 0.01 & -0.08 & -0.01 & -0.05 & 0.08 & $0.17^{* *}$ & -0.01 & 0.00 & -0.01 & -0.03 & -0.02 \\
\hline$c(4)$ & -0.06 & 0.02 & -0.08 & -0.04 & -0.13 & -0.04 & 0.11 & -0.04 & $-0.15^{* *}$ & 0.06 & -0.06 & -0.02 & -0.13 & -0.02 & 0.08 & -0.03 \\
\hline \multirow{4}{*}{$\begin{array}{l}\text { Sum(c) } \\
\text { Granger } \\
\text { causality } \\
\mathrm{R}^{2} \\
\mathrm{~N}\end{array}$} & -0.12 & -0.04 & -0.12 & -0.09 & -0.25 & -0.16 & -0.25 & -0.09 & -0.16 & 0.02 & -0.04 & -0.09 & -0.29 & -0.17 & -0.13 & -0.08 \\
\hline & 0.69 & 0.25 & $2.05^{*}$ & 1.56 & 1.30 & 1.24 & 1.90 & 1.42 & $2.13^{*}$ & 1.05 & $2.73^{* *}$ & $2.55^{* *}$ & 1.86 & 1.25 & 0.95 & $2.79^{* *}$ \\
\hline & 0.01 & 0.01 & 0.02 & 0.03 & 0.01 & 0.02 & 0.01 & 0.01 & 0.01 & 0.00 & 0.03 & 0.03 & 0.01 & 0.02 & 0.01 & 0.01 \\
\hline & 1144 & 1144 & 1144 & 1144 & 1144 & 1144 & 1144 & 8008 & 1144 & 1144 & 1144 & 1144 & 1144 & 1144 & 1144 & 8008 \\
\hline
\end{tabular}

Panel C: Ownership sorted

Equally weighted

Value weighted

\begin{tabular}{|c|c|c|c|c|c|c|c|c|c|c|c|c|c|c|c|c|}
\hline & & & & Equall & ighted & & & & & & & Value & ghted & & & \\
\hline Panel A: & nership s & d portfol & & & & & & & & & & & & & & \\
\hline & CAN & FRA & GER & ITA & JPN & UK & US & Pooled & CAN & FRA & GER & ITA & JPN & UK & US & Pooled \\
\hline & \multicolumn{16}{|c|}{ VAR results: low institutional ownership firms on high institutional ownership firms } \\
\hline $\mathrm{b}(1)$ & $0.23^{* *}$ & $0.09 * *$ & 0.04 & -0.08 & 0.02 & -0.03 & -0.21 & 0.04 & $0.24^{* *}$ & 0.05 & 0.03 & -0.07 & 0.07 & 0.05 & -0.18 & 0.00 \\
\hline $\mathrm{b}(2)$ & 0.04 & 0.05 & 0.01 & -0.05 & -0.10 & 0.05 & 0.04 & 0.02 & 0.03 & 0.07 & 0.02 & -0.06 & -0.12 & 0.05 & 0.12 & 0.00 \\
\hline$b(3)$ & 0.12 & 0.04 & $0.06^{* *}$ & $0.16^{* *}$ & -0.03 & -0.04 & -0.16 & 0.04 & 0.12 & 0.02 & $0.04 *$ & $0.19^{* *}$ & -0.01 & -0.02 & -0.26 & 0.02 \\
\hline $\mathrm{b}(4)$ & 0.02 & 0.00 & 0.01 & 0.05 & 0.03 & $0.28^{* * *}$ & 0.19 & 0.03 & 0.02 & -0.02 & 0.00 & 0.02 & -0.01 & $0.24^{* *}$ & 0.17 & -0.03 \\
\hline \multirow{4}{*}{$\begin{array}{l}\text { Sum(b) } \\
\text { Granger } \\
\text { causality } \\
\mathrm{R}^{2} \\
\mathrm{~N} \\
\end{array}$} & 0.41 & 0.17 & 0.13 & 0.08 & -0.07 & 0.26 & -0.13 & 0.13 & 0.41 & 0.12 & 0.09 & 0.08 & -0.07 & 0.32 & -0.16 & -0.01 \\
\hline & 1.77 & 1.70 & $2.27^{*}$ & 1.67 & 0.19 & $2.09^{*}$ & 0.72 & 1.57 & $1.98^{*}$ & 1.07 & 1.00 & 1.84 & 0.33 & 1.66 & 1.08 & 0.43 \\
\hline & 0.00 & 0.04 & 0.02 & 0.03 & 0.02 & 0.02 & 0.01 & 0.01 & 0.01 & 0.03 & 0.01 & 0.01 & 0.02 & 0.01 & 0.01 & 0.01 \\
\hline & 595 & 595 & 595 & 595 & 595 & 595 & 595 & 4165 & 595 & 595 & 595 & 595 & 595 & 595 & 595 & 4165 \\
\hline & \multicolumn{16}{|c|}{ VAR results: high institutional ownership firms on low institutional ownership firms } \\
\hline$c(1)$ & -0.13 & 0.12 & 0.02 & 0.06 & -0.12 & 0.07 & 0.12 & 0.00 & -0.12 & 0.02 & 0.13 & -0.07 & -0.16 & -0.06 & 0.14 & -0.03 \\
\hline$c(2)$ & -0.01 & -0.08 & 0.05 & 0.06 & 0.03 & -0.05 & -0.01 & 0.00 & 0.01 & -0.12 & 0.09 & 0.07 & 0.08 & -0.08 & -0.10 & 0.03 \\
\hline$c(3)$ & -0.05 & 0.18 & -0.22 & 0.05 & 0.06 & 0.15 & 0.15 & 0.01 & -0.06 & 0.16 & -0.13 & 0.02 & 0.05 & 0.12 & 0.26 & $0.06^{*}$ \\
\hline$c(4)$ & -0.02 & 0.01 & -0.05 & -0.11 & -0.18 & $-0.31^{* *}$ & -0.25 & -0.04 & -0.05 & 0.15 & 0.00 & -0.15 & -0.15 & $-0.27^{* *}$ & -0.20 & -0.02 \\
\hline $\operatorname{Sum}(\mathrm{c})$ & -0.21 & 0.23 & -0.21 & 0.06 & -0.20 & -0.14 & 0.01 & -0.03 & -0.22 & 0.21 & 0.09 & -0.13 & -0.17 & -0.29 & 0.11 & 0.04 \\
\hline $\begin{array}{l}\text { Granger } \\
\text { cuusality }\end{array}$ & 0.91 & 0.93 & 0.53 & 1.05 & 0.58 & $2.61^{* *}$ & 0.57 & 0.33 & 1.05 & 1.05 & 0.46 & 0.96 & 0.70 & $2.08^{*}$ & 0.85 & 1.34 \\
\hline $\mathrm{R}^{2}$ & 0.00 & 0.01 & 0.01 & 0.02 & 0.02 & 0.01 & 0.01 & 0.01 & 0.00 & 0.01 & 0.02 & 0.01 & 0.02 & 0.01 & 0.01 & 0.02 \\
\hline $\mathrm{N}$ & 595 & 595 & 595 & 595 & 595 & 595 & 595 & 4165 & 595 & 595 & 595 & 595 & 595 & 595 & 595 & 4165 \\
\hline
\end{tabular}

\subsubsection{Subperiod Analysis}

This section investigates the empirical stability of lead-lag relationships based on size and analyst coverage over time. The stability of lead-lag relationships over time is important from the perspective of an investor and it is also interesting in view of the academic literature on market efficiency. The question is if lead-lag relationships are getting arbitraged away over time. Fargher and Weigand (1998) study the lead-lag relationship in U.S. size sorted portfolios and find that the effect decreases over time. They argue that technologic and regulatory innovations (e.g. faster computers, the internet or the deregulation of commissions in the United States in 1975) have improved the response of small firms to common information.

To investigate this issue, we split our sample into two subsamples of equal length and perform Granger-causality tests on both subsamples. The first subsample is from 01/1990 to 12/2001 and the second subsample is from 01/2001 
to $12 / 2011$. Because the data on institutional ownership only starts in 2000 , we exclude portfolios sorted on institutional ownership from the test and concentrate on portfolios sorted on size and analyst coverage instead.

Table 4 panel A reports the results for the response of small firms with respect to large firms. The Granger-causality tests show that large firms Granger-cause small firms in 7 (6) out of 7 countries using equally (value) weighted portfolio returns in the first half of the sample. In the second half of the sample we find 6 significant Granger-causality tests using equally weighted and value weighted returns. Thus, the lead-lag effect in size portfolios is robust in a majority of countries for both subperiods. The Granger-causality tests for the pooled samples are also highly significant in both subsamples. The sum of the pooled coefficient estimates $\widehat{b_{k}}$ is $0.10(0.09)$ during the first half of the sample and $0.07(0.10)$ in the second half for equally (value) weighted portfolios. Therefore, the average lead-lag relationship across countries is similar in magnitude in both subsamples and does not appear to have substantially declined.

Table 4. In-sample Granger-causality tests: subsamples

This table reports the coefficient estimates and significance levels for the bivariate vector autoregressions with weekly stocks returns sorted by market capitalization and analyst coverage for subsamples. The first half of the sample is from 01/1990 - 12/2000, the second half is from 01/2001 - 12/2011. The portfolios sorted by analyst coverage are orthogonalized with respect to size as described in the text. Pooled denotes estimates obtained by pooling the observations from all countries. Let $R_{i, t}^{H}\left(R_{i, t}^{L}\right)$ denote the return on stocks with high (low) information frictions as indicated by low (high) market capitalization, low (high) analyst coverage or low (high) institutional ownership in country $i$, respectively. The bivariate vector autoregression is given by

$$
\begin{aligned}
& R_{i, t}^{H}=a_{0, i}+\sum_{k=1}^{K} a_{k, i} R_{i, t-k}^{H}+\sum_{k=1}^{K} b_{k, i} R_{i, t-k}^{L}+u_{i, t}, \\
& R_{i, t}^{L}=c_{0, i}+\sum_{k=1}^{K} c_{k, i} R_{i, t-k}^{H}+\sum_{k=1}^{K} d_{k, i} R_{i, t-k}^{L}+v_{i, t}^{L} .
\end{aligned}
$$

The table reports the coefficient estimates and significance levels of the lead-lag coefficients $\mathrm{b}(\mathrm{k})$ and $\mathrm{c}(\mathrm{k})$. The Granger-causality test tests the null hypothesis $b_{1, i}=\cdots=b_{K, i}=0 \quad\left(c_{1, i}=\cdots=c_{K, i}=0\right)$. Standard errors are computed using the Newey and West (1987) procedure. $\mathrm{R}^{2}$ is the adjusted $\mathrm{r}$-squared. $\mathrm{N}$ is the number of observations. $*, * *$ and $* * *$ denote statistical significance at the $10 \%, 5 \%$, and $1 \%$ level, respectively.

Panel A: Size sorted portfolios

Equally weighted

\begin{tabular}{|c|c|c|c|c|c|c|c|c|c|c|c|c|c|c|c|c|}
\hline \multicolumn{17}{|c|}{ Panel A: Size sorted portfolios } \\
\hline & $\mathrm{CAN}$ & FRA & GER & ITA & JPN & UK & US & Pooled & $\mathrm{CAN}$ & FRA & GER & ITA & JPN & UK & US & Pooled \\
\hline & \multicolumn{16}{|c|}{ First half of sample: $01 / 1990$ - 12/2000 } \\
\hline $\mathrm{b}(1)$ & $0.22^{*}$ & $0.15^{* * *}$ & $0.12^{* * *}$ & $0.17^{* * *}$ & $0.39^{* * *}$ & $0.19^{* * *}$ & $0.13^{* *}$ & $0.16^{* * *}$ & 0.06 & $0.09^{* * *}$ & $0.09^{* * *}$ & $0.12^{* * *}$ & $0.22^{* * *}$ & $0.12^{* * *}$ & 0.01 & $0.09^{* * *}$ \\
\hline$b(2)$ & -0.07 & 0.02 & 0.01 & 0.07 & 0.10 & $0.09^{*}$ & -0.04 & -0.01 & 0.02 & 0.01 & 0.01 & 0.04 & 0.02 & 0.00 & -0.03 & -0.01 \\
\hline $\mathrm{b}(3)$ & 0.11 & 0.01 & -0.02 & 0.03 & 0.06 & -0.01 & 0.01 & -0.01 & $0.15^{* * *}$ & 0.01 & 0.00 & 0.01 & 0.05 & 0.02 & 0.02 & 0.01 \\
\hline $\mathrm{b}(4)$ & $-0.22^{* * *}$ & 0.01 & 0.02 & -0.04 & $0.14^{* *}$ & 0.00 & 0.05 & -0.03 & -0.07 & 0.01 & 0.01 & 0.00 & $0.13^{* *}$ & 0.03 & 0.01 & 0.01 \\
\hline $\operatorname{Sum}(b)$ & 0.05 & 0.19 & 0.12 & 0.23 & 0.70 & 0.27 & 0.15 & 0.10 & 0.15 & 0.12 & 0.11 & 0.16 & 0.42 & 0.17 & 0.01 & 0.09 \\
\hline $\begin{array}{l}\text { Granger } \\
\text { causality }\end{array}$ & $4.95^{* * *}$ & $3.33^{* *}$ & $3.81^{* * *}$ & $2.17^{*}$ & $6.38^{* * *}$ & $4.51^{* * *}$ & $2.58^{* *}$ & $16.42^{* * *}$ & $3.05^{* *}$ & $2.22^{*}$ & $3.14^{* *}$ & $1.96^{*}$ & $4.09^{* * *}$ & $2.44^{* *}$ & 0.17 & $8.15^{* * *}$ \\
\hline & 0.44 & 0.29 & 0.17 & 0.13 & 0.15 & 0.28 & 0.23 & 0.34 & 0.37 & 0.26 & 0.13 & 0.10 & 0.13 & 0.25 & 0.17 & 0.26 \\
\hline \multirow[t]{2}{*}{$\mathrm{N}$} & 570 & 570 & 570 & 570 & 570 & 570 & 570 & 3990 & 570 & 570 & 570 & 570 & 570 & 570 & 570 & 3990 \\
\hline & \multicolumn{16}{|c|}{ Second half of sample: $01 / 2001-12 / 2011$} \\
\hline$c(1)$ & $0.24^{* * *}$ & $0.19^{* * *}$ & 0.07 & 0.06 & $0.17^{* * *}$ & $0.16^{* * *}$ & $0.25^{* * *}$ & $0.13^{* * *}$ & $0.25^{* * *}$ & $0.14^{* * *}$ & 0.04 & 0.07 & $0.13^{* * *}$ & $0.11^{* * *}$ & $0.25^{* * *}$ & $0.09^{* * *}$ \\
\hline$c(2)$ & 0.02 & 0.01 & 0.07 & 0.05 & -0.12 & 0.07 & 0.03 & 0.01 & 0.07 & 0.04 & 0.04 & 0.02 & -0.06 & $0.10^{* * *}$ & 0.02 & 0.02 \\
\hline$c(3)$ & 0.06 & 0.02 & 0.00 & $0.14^{*}$ & 0.07 & 0.04 & -0.05 & 0.03 & 0.10 & $0.07 * *$ & 0.01 & $0.15^{*}$ & 0.08 & 0.03 & -0.02 & $0.04^{* *}$ \\
\hline$c(4)$ & $-0.18^{*}$ & -0.06 & -0.10 & -0.11 & 0.00 & 0.02 & $-0.11^{* *}$ & $-0.09^{* * *}$ & $-0.14^{*}$ & -0.02 & -0.03 & -0.08 & 0.01 & 0.00 & -0.05 & $-0.05 * * *$ \\
\hline $\operatorname{Sum}(c)$ & 0.13 & 0.16 & 0.05 & 0.14 & 0.12 & 0.29 & 0.12 & 0.07 & 0.29 & 0.23 & 0.06 & 0.15 & 0.16 & 0.25 & 0.20 & 0.10 \\
\hline $\begin{array}{l}\text { Granger } \\
\text { causality }\end{array}$ & $5.31^{* * *}$ & $4.13^{* * *}$ & 1.13 & $2.08^{*}$ & $3.42^{* * *}$ & $4.42^{* * *}$ & $5.18^{* * *}$ & $14.17^{* * *}$ & $7.33^{* * *}$ & $4.01^{* * *}$ & 0.58 & $2.36^{*}$ & $2.44^{* *}$ & $3.29^{* *}$ & $2.93^{* *}$ & $10.20^{* * *}$ \\
\hline $\mathrm{R}^{2}$ & 0.36 & 0.17 & 0.15 & 0.05 & 0.02 & 0.33 & 0.12 & 0.21 & 0.28 & 0.16 & 0.11 & 0.04 & 0.02 & 0.30 & 0.08 & 0.15 \\
\hline $\mathrm{N}$ & 570 & 570 & 570 & 570 & 570 & 570 & 570 & 3990 & 570 & 570 & 570 & 570 & 570 & 570 & 570 & 3990 \\
\hline
\end{tabular}

Value weighted 


\begin{tabular}{|c|c|c|c|c|c|c|c|c|c|c|c|c|c|c|c|c|}
\hline \multicolumn{17}{|c|}{ Panel A: Analyst sorted portfolios } \\
\hline & CAN & FRA & GER & ITA & JPN & UK & US & Pooled & CAN & FRA & GER & ITA & JPN & UK & US & Pooled \\
\hline & \multicolumn{16}{|c|}{ First half of sample: $01 / 1990$ - 12/2000 } \\
\hline $\mathrm{b}(1)$ & $0.17^{* * *}$ & $0.15^{* * *}$ & $0.08^{* *}$ & $0.12^{*}$ & $0.52^{* * *}$ & $0.13^{*}$ & $0.21^{* *}$ & $0.16^{* * * *}$ & $0.17^{* * *}$ & 0.09 & $0.08^{* *}$ & 0.09 & $0.37^{* *}$ & $0.18^{* * *}$ & 0.13 & $0.13^{* * *}$ \\
\hline$b(2)$ & 0.01 & 0.10 & $0.12^{* * *}$ & 0.06 & 0.19 & 0.05 & -0.02 & $0.07^{* *}$ & -0.05 & 0.09 & $0.10^{* *}$ & 0.01 & 0.25 & 0.01 & 0.02 & 0.05 \\
\hline $\mathrm{b}(3)$ & 0.02 & -0.05 & $0.09 *$ & $0.18^{* *}$ & 0.10 & 0.02 & $-0.17^{*}$ & 0.05 & 0.01 & -0.05 & 0.05 & $0.21^{* * *}$ & 0.12 & 0.02 & -0.13 & 0.05 \\
\hline$b(4)$ & -0.02 & 0.00 & 0.02 & -0.11 & 0.19 & $-0.11^{*}$ & -0.04 & -0.03 & -0.03 & 0.00 & 0.00 & -0.10 & 0.13 & -0.06 & -0.09 & -0.03 \\
\hline \multirow{3}{*}{$\begin{array}{l}\text { Sum(b) } \\
\text { Granger } \\
\text { causality } \\
\mathrm{R}^{2} \\
\mathrm{~N}\end{array}$} & 0.18 & 0.20 & 0.30 & 0.24 & 1.00 & 0.08 & -0.02 & 0.24 & 0.10 & 0.14 & 0.22 & 0.21 & 0.86 & 0.16 & -0.08 & 0.19 \\
\hline & $4.51^{* * *}$ & $3.22^{* *}$ & $6.59^{* * *}$ & $2.31^{*}$ & $5.38^{* * *}$ & 1.48 & 1.41 & $16.98^{* * *}$ & $4.28^{* * *}$ & 1.16 & $4.54^{* * *}$ & 1.92 & $4.93^{* * *}$ & $2.41^{* *}$ & 1.26 & $12.17^{* * *}$ \\
\hline & $\begin{array}{l}0.07 \\
570\end{array}$ & $\begin{array}{l}0.14 \\
570\end{array}$ & $\begin{array}{l}0.07 \\
570\end{array}$ & $\begin{array}{l}0.08 \\
570\end{array}$ & $\begin{array}{l}0.07 \\
570\end{array}$ & $\begin{array}{l}0.23 \\
570\end{array}$ & $\begin{array}{l}0.06 \\
570\end{array}$ & $\begin{array}{l}0.08 \\
3990\end{array}$ & $\begin{array}{l}0.07 \\
570\end{array}$ & $\begin{array}{l}0.09 \\
570\end{array}$ & $\begin{array}{l}0.06 \\
570\end{array}$ & $\begin{array}{l}0.08 \\
570\end{array}$ & $\begin{array}{l}0.05 \\
570\end{array}$ & $\begin{array}{l}0.20 \\
570\end{array}$ & $\begin{array}{l}0.02 \\
570\end{array}$ & $\begin{array}{l}0.06 \\
3990\end{array}$ \\
\hline & \multicolumn{16}{|c|}{ Second half of sample: $01 / 2001-12 / 2011$} \\
\hline$c(1)$ & 0.10 & $0.13^{* * *}$ & $0.24^{* * *}$ & 0.08 & $0.27^{* *}$ & $0.17^{* * *}$ & 0.08 & $0.13^{* * *}$ & 0.03 & $0.08^{* *}$ & $0.11^{* *}$ & 0.05 & $0.19^{*}$ & $0.12^{* *}$ & 0.01 & $0.07 * * *$ \\
\hline$c(2)$ & -0.07 & 0.00 & -0.03 & -0.03 & -0.13 & 0.09 & 0.00 & -0.01 & -0.03 & 0.03 & 0.04 & -0.01 & -0.12 & 0.02 & 0.04 & 0.01 \\
\hline$c(3)$ & 0.03 & 0.05 & 0.04 & 0.09 & -0.06 & 0.07 & $0.19^{* *}$ & $0.06^{* *}$ & 0.12 & 0.01 & 0.05 & 0.06 & -0.13 & 0.10 & $0.25^{* * *}$ & $0.06^{* * *}$ \\
\hline$c(4)$ & -0.04 & -0.01 & $-0.11^{*}$ & 0.02 & -0.12 & 0.07 & 0.01 & -0.03 & -0.02 & -0.03 & -0.03 & 0.00 & -0.05 & 0.05 & -0.04 & -0.01 \\
\hline \multirow{4}{*}{$\begin{array}{l}\text { Sum(c) } \\
\text { Granger } \\
\text { causality } \\
\mathrm{R}^{2} \\
\mathrm{~N}\end{array}$} & 0.01 & 0.17 & 0.14 & 0.17 & -0.03 & 0.40 & 0.28 & 0.15 & 0.10 & 0.10 & 0.17 & 0.09 & -0.11 & 0.30 & 0.26 & 0.13 \\
\hline & 0.87 & $3.72^{* * *}$ & $4.54^{* * *}$ & 0.83 & $2.34^{*}$ & $3.83^{* * *}$ & 1.77 & $10.84^{* * *}$ & 0.63 & 1.50 & 1.68 & 0.53 & 1.61 & $2.50^{* *}$ & $2.96^{* *}$ & $5.33^{* * *}$ \\
\hline & $\begin{array}{l}0.08 \\
570\end{array}$ & $\begin{array}{l}0.12 \\
570\end{array}$ & $\begin{array}{l}0.09 \\
570\end{array}$ & $\begin{array}{l}0.05 \\
570\end{array}$ & $\begin{array}{l}0.02 \\
570\end{array}$ & $\begin{array}{l}0.19 \\
570\end{array}$ & $\begin{array}{l}0.01 \\
570\end{array}$ & $\begin{array}{l}0.06 \\
3990\end{array}$ & $\begin{array}{l}0.04 \\
570\end{array}$ & 0.09 & 0.06 & 0.02 & 0.01 & 0.12 & 0.01 & 0.03 \\
\hline & 570 & 570 & 570 & 570 & 570 & 570 & 570 & 3990 & 570 & 570 & 570 & 570 & 570 & 570 & 570 & 3990 \\
\hline
\end{tabular}

Panel B reports the subsample results for lead-lag effects in analyst sorted portfolios. We find significant lead-lag relationships in 5 (4) countries using equal (value) weighted returns in the first half of the sample and 4 (2) significant Granger-causality relationships in the second half of the sample. The sum of the pooled coefficients is $0.24(0.19)$ in the first half of the sample and $0.15(0.13)$ in the second half of the sample for equally (value) weighted portfolios. Therefore, we observe a decline in the average lead-lag effect in analyst-sorted portfolios.

Overall, our subsample analysis shows that the lead-lag relationships documented above exist in both halves of the sample period. Especially the lead-lag relationships based on size portfolios are remarkably robust over time. The lead-lag relationships according to analyst coverage are lower during the second half of the sample. We interpret our results as mild evidence for more efficient markets in recent years as argued by Fargher and Weigand (1998).

\section{Out-of-sample Analysis}

In an influential paper, Goyal and Welch (2008) study a broad range of predictors for aggregate U.S. stock market returns. They show that most known predictors, even those with a statistically significant in-sample performance, produce unstable forecasts over time and cannot outperform the prevailing sample mean forecast in out-of-sample tests. Therefore, significant in-sample predictability does not necessarily indicate that an investor could utilize a predictive relationship for real-time forecasts. Based on these findings, the attention of academic researcher has shifted in recent years from pure in-sample tests to out-of-sample return predictability (e.g. Campbell and Thompson (2008), Pastor and Stambaugh (2009), Van Binsbergen and Koijen (2010), Ferreira and Santa-Clara (2011)) (Note 19).

This section applies out-of-sample tests to lead-lag relationships between low friction and high friction stocks. To our best knowledge, we are the first to comprehensively study lead-lag relationships using the out-of-sample methodology. (Note 20) The question is if the in-sample predictability of high friction firms documented in Table 2 translates into significant out-of-sample predictability. The out-of-sample analysis is an interesting robustness check and it is also important from the perspective of an investor for real-time forecasting.

Out-of-sample tests are based on the forecast comparison between two or more competing models. Following the framework of Goyal and Welch (2008), we focus on simple linear predictive regressions, which predict the one-period-ahead returns of high friction stocks with lagged returns on low friction stocks

$$
R_{i, t+1}^{H}=a_{i}+b_{i} R_{i, t}^{L}+\varepsilon_{i, t} .
$$

The classic benchmark model in the return predictability literature is the sample mean, which is tantamount to the common hypothesis that stock returns are unpredictable

$$
R_{i, t+1}^{H}=a_{i}+\varepsilon_{i, t}
$$


Then the expected returns of the high friction portfolio according to the predictive model and the benchmark model are

and

$$
\mu_{p, i, t+1}=\hat{a}_{i}+\hat{b}_{i} R_{i, t}^{L}
$$

$$
\mu_{b, i, t+1}=\hat{a}_{i}
$$

where $\mu_{p, i, t+1}$ and $\mu_{b, i, t+1}$ denote the expected one-period-ahead return according the predictive model and the benchmark model, respectively. We use an initial estimation period of 5 years (01/1990 to 12/1994) to generate the first set of forecasts. The forecast evaluation period is from 01/1995 to 12/2011. Because of the limited sample period of institutional ownership data, we perform the out-of-sample tests with portfolios sorted on size and analyst coverage, which are available for the entire sample period. The sequences of one-period-ahead forecasts $\left\{\mu_{p, i, t+1}\right\}_{t=M}^{T-1}$ and $\left\{\mu_{b, i, t+1}\right\}_{t=M}^{T-1}$ are estimated using an expanding estimation window. This forecasting exercise is conducted with equally weighted portfolio returns. (Note 21 )

Note that the seminal articles of Lo and MacKinlay (1990) and Brennan, Chordia and Swaminathan (1993) have been published before 1995, which corresponds to the start of the forecast evaluation period. Thus, the knowledge about the existence of lead-lag relationships in stock returns was already available at the time and could have been used by an investor.

In order to evaluate the out-of-sample forecast performance, we use the Campbell and Thompson (2008) $R_{O S}^{2}$ statistic (for simplicity we suppress the country index i)

$$
R_{O S}^{2}=1-\frac{M S E_{p}}{M S E_{b}}=\frac{\sum_{t=M}^{T-1}\left(R_{t+1}^{H}-\mu_{p, t+1}\right)^{2}}{\sum_{t=M}^{T-1}\left(R_{t+1}^{H}-\mu_{b, t+1}\right)^{2}} .
$$

$M S E_{p}$ and $M S E_{b}$ denote the mean square forecast errors of the predictive and benchmark models. (Note 22) If $R_{O S}^{2}$ is positive, the predictive model outperforms the sample mean in terms of mean square error. Statistical significance is tested with the Clark and West (2007) adjusted MSPE statistic. The null hypothesis of this test is $M S E_{p}=M S E_{b}$, which is tested against the one sided alternative $M S E_{p}<M S E_{b}$. The limiting distribution of the adjusted MSPE statistic under the null hypothesis is approximately standard normal. This test is explicitly designed for nested forecast models, which are employed here.

Table 5 presents $R_{O S}^{2}$ statistics and adjusted MSPE statistics for lead-lag relationships based on size and analyst coverage sorted portfolios. We also present results for weekly and monthly return forecasts. Panel A shows that the weekly $R_{O S}^{2}$ statistics are positive and significant for each country in the sample. The $R_{O S}^{2}$ calculated on a monthly basis are significant for 6 of the 7 countries. The average $R_{O S}^{2}$ is 4.20 (5.71) for a weekly (monthly) forecast horizon. Thus, the returns on small firms are clearly predictable out-of-sample using the lagged returns of large firms as predictor.

Table 5. Out-of-sample predictability

The table reports the results of out-of-sample return predictability tests based on lead-lag relationships. Let $R_{i, t}^{H}\left(R_{i, t}^{L}\right)$ denote the return on stocks with high (low) information frictions as indicated by low (high) market capitalization or low (high) analyst coverage in country $\mathrm{i}$, respectively. The forecast performance of the predictive regression $R_{i, t+1}^{H}=a_{i}+b_{i} R_{i, t}^{L}+\varepsilon_{i, t}$ is compared to the prevailing sample mean benchmark $R_{i, t+1}^{H}=a_{i}+\varepsilon_{i, t}$. The initial estimation period is from $01 / 1990$ to $12 / 1994$ and the forecast evaluation period is from $1 / 1995$ to $12 / 2011$. The comparison in terms of means square prediction error (MSPE) is based on the Campbell and Thomson (2008) out-of-sample $\mathrm{R}^{2}$ statistic and statistical significance is established using the Clark and West (2007) adjusted MSPE statistic, which is asymptotically standard normal. *,** and *** denote statistical significance at the $10 \%, 5 \%$, and $1 \%$ level, respectively.

\begin{tabular}{lcccc}
\hline & \multicolumn{2}{c}{ Weekly forecast } & \multicolumn{2}{c}{ Monthly forecast } \\
\hline \multicolumn{1}{c}{$\boldsymbol{R}_{\boldsymbol{O} \text { S }}^{2}$} & $\begin{array}{c}\text { Adj. MSPE } \\
\text { statistic }\end{array}$ & $\boldsymbol{R}_{\boldsymbol{O} \text { S }}^{2}$ & $\begin{array}{c}\text { Adj. MSPE } \\
\text { statistic }\end{array}$ \\
\hline Panel A: Size portfolios & & & \\
\hline CAN & $6.74^{* * *}$ & 5.43 & $9.59^{* * *}$ & 3.47 \\
FRA & $7.34^{* * *}$ & 5.45 & $8.38^{* * *}$ & 3.52 \\
GER & $2.79^{* * *}$ & 3.24 & $2.86^{*}$ & 1.50
\end{tabular}




$\begin{array}{lllll}\text { ITA } & 3.72 * * * & 4.13 & -0.34 & 0.71 \\ \text { JPN } & 0.56^{* * *} & 2.06 & 1.55^{*} & 1.46 \\ \text { UK } & 2.09^{* * *} & 3.56 & 6.13^{* * *} & 2.93 \\ \text { US } & 6.13^{* * *} & 5.25 & 11.80^{* * *} & 3.57\end{array}$

\begin{tabular}{lcccc} 
Average & 4.20 & \multicolumn{3}{c}{5.71} \\
\hline \multicolumn{2}{l}{ Panel B: Analyst portfolios } & & & \\
\hline CAN & $3.02^{* * *}$ & 3.15 & $5.51^{* * *}$ & 2.20 \\
FRA & $5.58^{* * *}$ & 5.04 & $2.45^{* * *}$ & 2.43 \\
GER & $5.51^{* * *}$ & 4.17 & 0.30 & 0.84 \\
ITA & $3.85^{* * *}$ & 4.01 & $1.79^{*}$ & 1.55 \\
JPN & -0.28 & 0.88 & -0.85 & -0.68 \\
UK & $2.25 * * *$ & 3.79 & 0.73 & 1.25 \\
US & -0.10 & 1.07 & $2.85^{* * *}$ & 2.25 \\
& & & & \\
Average & 2.83 & & 1.83 & \\
\hline
\end{tabular}

Panel B shows the results with analyst coverage portfolios. The few analyst portfolio experiences significant out-of-sample predictability in 5 (4) countries using lagged returns of the many analyst portfolio as predictor. The average $R_{O S}^{2}$ statistic is 2.83 (1.83) for the weekly (monthly) forecast interval. Hence, analyst portfolios exhibit less out-of-sample predictability than size portfolios according to the number of significant predictive relationships and the average $R_{O S}^{2}$ statistics.

\section{Profitability of Lead-Lag Relationships}

\subsection{Without Transaction Costs}

The previous results have shown that the returns on stocks with high information frictions exhibit significant in-sample and out-of-sample predictability across major developed markets. This section investigates if this time-series predictability could be exploited by a real-world investor in order to generate positive abnormal returns on a risk-adjusted basis. Analogous to the out-of-sample methodology discussed in the previous section, an investor could predict the portfolio returns of high frictions stocks using lagged portfolio returns of low friction stocks. Then an investor could time the market by buying the high friction portfolio if its expected return is positive.

The question about the profitability of lead-lag relationships in practice is related to the academic literature that explores the profitability of various market anomalies such as size, value or momentum after trading costs (e.g. Keim and Madhavan (1997), Korajczyk and Sadka (2004), Lesmond, Shill and Zhou (2004), Frazzini, Israel and Moskowitz (2012), Novy-Marx and Velikov (2015), Schmidt, Schrimpf, von Arx, Wagner and Ziegler (2015)). However, none of these studies investigates the profitability of lead-lag relationships in stock returns. To our best knowledge, Knez and Ready (1996) is the only existing study on this issue. Knez and Ready (1996) find that profits generated by a trading strategy that attempts to exploit lead-lag relationships based on firm size in the U.S. market are swamped by trading costs. However, their study differs from our study in several important aspects. First, Knez and Ready (1996) use a different trading strategy that invests in both small- and large firm portfolios. However, the empirical evidence suggests that only returns on firms with high information frictions are predictable in the short term, whereas the returns on firms with low information frictions are close to unpredictable (e.g. Goyal and Welch (2008)). Therefore, our trading strategy is specifically designed to exploit the predictability of high information friction stocks. Second, Knez and Ready (1996) use a relatively short period of five years (1988-1992) to assess the profitability of their trading strategy. In contrast, our entire sample spans 22 years and we use 17 years (1995-2011) to assess the profitability of our market timing strategy. Third, the analysis in Knez and Ready (1996) only considers weekly raw returns without adjusting the returns for common risk factors. In contrast, we investigate the profitability of our trading strategy for weekly and monthly returns and our analysis focuses on abnormal returns according to the Carhart (1997) four-factor model. Fourth, the results in Knez and Ready (1996) are solely based on U.S. stocks, whereas we study our trading strategy across seven developed markets. Even if a trading strategy is not able to generate significant abnormal returns in the U.S. market, it still might be profitable in other countries, where lead-lag effects are more pronounced.

Our trading strategy is based on the out-of-sample methodology and utilizes the simple linear predictive regression (3) to predict the returns on high friction stocks with lagged returns on low friction stocks. (Note 23) When the 
conditional expected return of the high friction portfolio is positive, the investor buys the portfolio. If the conditional expected return is zero or negative, we assume that the investor simply holds cash. Alternatively, one could assume that the investor tries to short the high friction portfolio when its expected return is negative. However, our objective is to design a trading strategy that could be implemented by a real-world investor and it is likely that high friction stocks are very difficult or even impossible to short in practice. Following the discussions in Keim (1999) and Fama and French (2008), we also exclude all micro caps with a market capitalization below the 20\% NYSE quantile from the trading strategy. As discussed above, market frictions related to liquidity may be too large to trade these stocks in a timely manner. We implement the trading strategy on a weekly and on a monthly basis. The return of the strategy is given by

$$
\text { strategyt }=\left\{\begin{array}{cl}
R_{t+1}^{H} & \text {, if } E\left[R_{t+1}^{H}\right]>0 \\
0 & \text {, if } E\left[R_{t+1}^{H}\right] \leq 0 .
\end{array}\right.
$$

To test if this strategy is able to generate a significant abnormal return, we adjust the returns for common risk factors utilizing the four-factor model of Carhart (1997) and Fama and French (1993, 2012). We construct the four risk factors for each individual country in our sample and for weekly as well as monthly returns. The risk factors are defined as the return on the local market portfolio in excess of the local risk free rate (MKT- $R_{f}$ ), the return on small stocks minus the return on big stocks (SMB), the return on high book-to-market stocks minus the returns on low book-to-market stocks (HML) and the returns of past winners minus the returns of past losers (WML). We use local 3-month T-bill rates to calculate excess returns of the local market portfolio. All factor returns are denominated in local currency. Then we test if the excess returns generated by our trading strategy are spanned by the four factors using the following regression

$$
\text { strategy }_{t}-R_{f, t}=a+b\left(M K T_{t}-R_{f, t}\right)+c S M B_{t}+d H M L_{t}+e W M L_{t}+\varepsilon_{t} .
$$

Table 6 shows the estimated alphas, factor loadings and corresponding t-statistics for the trading strategy implemented with portfolios sorted on size and analyst coverage. Panel A shows that the alphas are significant in several countries for the strategy based size portfolios.

Specifically, the trading strategy yields significant abnormal returns in 4 out of 7 countries based on weekly and monthly returns. The alphas are significant for Canada, France, Japan and the United Kingdom when the strategy is implemented with weekly returns. Using monthly returns, the alphas are significant for France, Germany, the United Kingdom and the United States. The annualized monthly alphas range from $2.91 \%$ in Japan to $7.42 \%$ in the United Kingdom. The factor loadings show that the trading strategy is highly correlated with the market factor and the size factor, which is expected because the strategy is long only. The loadings on the HML factor are mainly positive and mainly negative for the WML factor.

Table 6. Trading strategy results before costs

This table presents abnormal returns and factor loadings of a trading strategy that attempts to exploit the return predictability of lead-lag relationships among portfolios sorted by market capitalization and analyst coverage. Abnormal returns are calculated using the Carhart (1997) four-factor model. The sample period is 01/1990 - 12/2011. Micro caps, defined as firms with a market capitalization below the 20\% NYSE quintile are excluded. Let $R_{i, t}^{H}\left(R_{i, t}^{L}\right)$ denote the return on stocks with high (low) information frictions as indicated by low (high) market capitalization and low (high) analyst coverage in country $i$, respectively. The trading strategy invests in a portfolio of stocks stocks with high information frictions if the expected return is positive and holds cash, else. Return forecasts are based on the predictive regression $R_{i, t+1}^{H}=a_{i}+b_{i} R_{i, t}^{L}+\varepsilon_{i, t}$. The returns of the trading strategy are given by strategy $y_{t}=$ $\left\{\begin{array}{cl}R_{t+1}^{H} & \text {, if } E\left[R_{t+1}^{H}\right]>0 \\ 0 & \text {, if } E\left[R_{t+1}^{H}\right] \leq 0 .\end{array}\right.$ Standard errors are computed using the Newey and West (1987) procedure. *, ** and *** denote statistical significance at the $10 \%, 5 \%$, and $1 \%$ level, respectively. 
Panel A: Size portfolios

\begin{tabular}{|c|c|c|c|c|c|c|c|}
\hline & CAN & FRA & GER & ITA & JPN & UK & US \\
\hline \multicolumn{8}{|c|}{ Panel A : Size portfolios } \\
\hline \multicolumn{8}{|c|}{ Weekly returns } \\
\hline alpha & $\begin{array}{l}0.10 * * \\
(2.07)\end{array}$ & $\begin{array}{c}0.15 * * * \\
(3.15)\end{array}$ & $\begin{array}{c}0.07 \\
(1.64)\end{array}$ & $\begin{array}{c}0.08 \\
(1.26)\end{array}$ & $\begin{array}{c}0.11 * * \\
(2.34)\end{array}$ & $\begin{array}{c}0.15 * * * \\
(2.99)\end{array}$ & $\begin{array}{c}0.04 \\
(0.77)\end{array}$ \\
\hline MKT & $\begin{array}{c}0.57 * * * \\
(9.37)\end{array}$ & $\begin{array}{c}0.64 * * * \\
(12.68)\end{array}$ & $\begin{array}{c}0.58 * * * \\
(9.91)\end{array}$ & $\begin{array}{c}0.52 * * * \\
(12.01)\end{array}$ & $\begin{array}{c}0.42 * * * \\
(9.37)\end{array}$ & $\begin{array}{c}0.60 * * * \\
(12.63)\end{array}$ & $\begin{array}{c}0.70 * * * \\
(11.89)\end{array}$ \\
\hline SMB & $\begin{array}{c}0.22 * * * \\
(4.07)\end{array}$ & $\begin{array}{c}0.58 * * * \\
(10.63)\end{array}$ & $\begin{array}{c}0.43 * * * * \\
(5.96)\end{array}$ & $\begin{array}{c}0.50 * * * \\
(8.12)\end{array}$ & $\begin{array}{c}0.32 * * * \\
(5.44)\end{array}$ & $\begin{array}{c}0.48 * * * \\
(9.61)\end{array}$ & $\begin{array}{c}0.81 * * * \\
(14.95)\end{array}$ \\
\hline HML & $\begin{array}{c}0.06 \\
(1.24)\end{array}$ & $\begin{array}{l}0.06^{*} \\
(1.87)\end{array}$ & $\begin{array}{c}0.04 \\
(0.93)\end{array}$ & $\begin{array}{c}0.19 * * * \\
(4.35)\end{array}$ & $\begin{array}{c}0.21 * * * \\
(5.00)\end{array}$ & $\begin{array}{l}0.10^{*} \\
(1.92)\end{array}$ & $\begin{array}{c}0.20 * * * \\
(3.36)\end{array}$ \\
\hline WML & $\begin{array}{c}-0.03 \\
(-1.02)\end{array}$ & $\begin{array}{c}0.01 \\
(0.27)\end{array}$ & $\begin{array}{c}-0.03 \\
(-1.15)\end{array}$ & $\begin{array}{c}-0.03 \\
(-0.88)\end{array}$ & $\begin{array}{c}-0.05 \\
(-1.44)\end{array}$ & $\begin{array}{c}-0.08 * * \\
(-2.48)\end{array}$ & $\begin{array}{c}-0.09 * * * \\
(-2.85)\end{array}$ \\
\hline \multicolumn{8}{|c|}{ Monthly returns } \\
\hline alpha & $\begin{array}{c}0.28 \\
(1.11)\end{array}$ & $\begin{array}{c}0.43^{* *} \\
(2.18)\end{array}$ & $\begin{array}{l}0.33^{*} \\
(1.67)\end{array}$ & $\begin{array}{c}0.30 \\
(1.17)\end{array}$ & $\begin{array}{c}0.24 \\
(1.16)\end{array}$ & $\begin{array}{c}0.62 * * * \\
(2.82)\end{array}$ & $\begin{array}{l}0.38^{*} \\
(1.67)\end{array}$ \\
\hline MKT & $\begin{array}{c}0.72 * * * \\
(6.64)\end{array}$ & $\begin{array}{c}0.72 * * * \\
(9.65)\end{array}$ & $\begin{array}{c}0.74 * * * \\
(10.04)\end{array}$ & $\begin{array}{c}0.76^{* * * *} \\
(9.89)\end{array}$ & $\begin{array}{c}0.39 * * * \\
(7.10)\end{array}$ & $\begin{array}{c}0.69 * * * \\
(8.21)\end{array}$ & $\begin{array}{c}0.72 * * * \\
(7.46)\end{array}$ \\
\hline SMB & $\begin{array}{c}0.38 * * * \\
(3.29)\end{array}$ & $\begin{array}{c}0.68 * * * \\
(9.09)\end{array}$ & $\begin{array}{c}0.63 * * * \\
(7.76)\end{array}$ & $\begin{array}{c}0.75 * * * \\
(8.13)\end{array}$ & $\begin{array}{c}0.30 * * * \\
(3.03)\end{array}$ & $\begin{array}{c}0.54 * * * \\
(6.38)\end{array}$ & $\begin{array}{c}0.82 * * * \\
(10.11)\end{array}$ \\
\hline HML & $\begin{array}{c}0.07 \\
(0.82)\end{array}$ & $\begin{array}{c}0.14 * * \\
(1.97)\end{array}$ & $\begin{array}{c}-0.01 \\
(-0.11)\end{array}$ & $\begin{array}{c}0.10 \\
(1.10)\end{array}$ & $\begin{array}{c}0.21 * * * \\
(2.73)\end{array}$ & $\begin{array}{c}0.09 \\
(1.07)\end{array}$ & $\begin{array}{c}0.03 \\
(0.36)\end{array}$ \\
\hline WML & $\begin{array}{c}-0.04 \\
(-0.93)\end{array}$ & $\begin{array}{c}-0.03 \\
(-0.64)\end{array}$ & $\begin{array}{c}0.04 \\
(0.65)\end{array}$ & $\begin{array}{c}-0.05 \\
(-0.88)\end{array}$ & $\begin{array}{c}0.03 \\
(0.47)\end{array}$ & $\begin{array}{c}-0.12^{* *} \\
(-1.98)\end{array}$ & $\begin{array}{l}-0.10^{*} \\
(-1.91)\end{array}$ \\
\hline \multicolumn{8}{|c|}{ Panel B: Analyst coverage portfolios } \\
\hline & CAN & FRA & GER & ITA & JPN & UK & US \\
\hline \multicolumn{8}{|c|}{ Panel A : Analyst portfolios } \\
\hline \multicolumn{8}{|c|}{ Weekly returns } \\
\hline alpha & $\begin{array}{l}0.08^{*} \\
(1.67)\end{array}$ & $\begin{array}{c}0.14 * * * \\
(3.18)\end{array}$ & $\begin{array}{c}0.11 * * \\
(2.58)\end{array}$ & $\begin{array}{l}0.10 * * \\
(2.07)\end{array}$ & $\begin{array}{c}0.05 \\
(1.19)\end{array}$ & $\begin{array}{c}0.10^{* *} \\
(2.01)\end{array}$ & $\begin{array}{l}-0.01 \\
(-0.24)\end{array}$ \\
\hline MKT & $\begin{array}{c}0.54 * * * \\
(9.56)\end{array}$ & $\begin{array}{c}0.52 * * * \\
(11.21)\end{array}$ & $\begin{array}{c}0.50 * * * \\
(9.84)\end{array}$ & $\begin{array}{c}0.44 * * * \\
(10.55)\end{array}$ & $\begin{array}{c}0.24 * * * \\
(8.12)\end{array}$ & $\begin{array}{c}0.57 * * * \\
(11.19)\end{array}$ & $\begin{array}{c}0.86 * * * \\
(25.39)\end{array}$ \\
\hline SMB & $\begin{array}{c}0.24 * * * \\
(4.78)\end{array}$ & $\begin{array}{c}0.47 * * * \\
(9.48)\end{array}$ & $\begin{array}{c}0.39 * * * \\
(6.27)\end{array}$ & $\begin{array}{c}0.40 * * * \\
(5.97)\end{array}$ & $\begin{array}{c}0.08^{*} \\
(1.66)\end{array}$ & $\begin{array}{c}0.42 * * * \\
(8.58)\end{array}$ & $\begin{array}{c}0.80 * * * \\
(17.35)\end{array}$ \\
\hline HML & $\begin{array}{l}0.08^{*} \\
(1.96)\end{array}$ & $\begin{array}{l}0.08 * * \\
(2.34)\end{array}$ & $\begin{array}{c}0.02 \\
(0.31)\end{array}$ & $\begin{array}{c}0.18^{* * *} \\
(3.18)\end{array}$ & $\begin{array}{c}0.15 * * * \\
(3.98)\end{array}$ & $\begin{array}{c}0.06 \\
(1.27)\end{array}$ & $\begin{array}{c}0.30 * * * \\
(6.65)\end{array}$ \\
\hline WML & $\begin{array}{c}0.03 \\
(1.15)\end{array}$ & $\begin{array}{c}0.03 \\
(0.80)\end{array}$ & $\begin{array}{c}-0.04 \\
(-1.39)\end{array}$ & $\begin{array}{c}0.01 \\
(0.27)\end{array}$ & $\begin{array}{c}-0.02 \\
(-0.61)\end{array}$ & $\begin{array}{c}0.02 \\
(0.64)\end{array}$ & $\begin{array}{l}0.05 * * \\
(2.32)\end{array}$ \\
\hline \multicolumn{8}{|c|}{ Monthly returns } \\
\hline alpha & $\begin{array}{c}0.39 \\
(1.56)\end{array}$ & $\begin{array}{c}0.21 \\
(1.02)\end{array}$ & $\begin{array}{c}0.46 * * \\
(2.40)\end{array}$ & $\begin{array}{l}0.41^{*} \\
(1.68)\end{array}$ & $\begin{array}{c}-0.04 \\
(-0.31)\end{array}$ & $\begin{array}{c}0.36 \\
(1.49)\end{array}$ & $\begin{array}{l}-0.03 \\
(-0.16)\end{array}$ \\
\hline MKT & $\begin{array}{c}0.58 * * * \\
(6.51)\end{array}$ & $\begin{array}{c}0.72 * * * \\
(9.02)\end{array}$ & $\begin{array}{c}0.62 * * * \\
(10.07)\end{array}$ & $\begin{array}{c}0.66 * * * \\
(7.43)\end{array}$ & $\begin{array}{l}0.08 * * \\
(2.53)\end{array}$ & $\begin{array}{c}0.76 * * * \\
(9.31)\end{array}$ & $\begin{array}{c}0.81 * * * \\
(10.20)\end{array}$ \\
\hline SMB & $\begin{array}{c}0.35 * * * \\
(3.76)\end{array}$ & $\begin{array}{c}0.75 * * * \\
(9.69)\end{array}$ & $\begin{array}{c}0.56 * * * \\
(7.96)\end{array}$ & $\begin{array}{c}0.70 * * * \\
(6.07)\end{array}$ & $\begin{array}{c}0.09 \\
(1.48)\end{array}$ & $\begin{array}{c}0.57 * * * \\
(8.02)\end{array}$ & $\begin{array}{c}0.79 * * * \\
(14.92)\end{array}$ \\
\hline HML & $\begin{array}{l}0.13^{*} \\
(1.69)\end{array}$ & $\begin{array}{c}0.03 \\
(0.38)\end{array}$ & $\begin{array}{c}0.05 \\
(0.52)\end{array}$ & $\begin{array}{c}0.09 \\
(0.64)\end{array}$ & $\begin{array}{c}0.00 \\
(-0.04)\end{array}$ & $\begin{array}{c}-0.16 \\
(-1.63)\end{array}$ & $\begin{array}{c}0.17 * * * \\
(2.72)\end{array}$ \\
\hline WML & $\begin{array}{l}0.06^{*} \\
(1.89)\end{array}$ & $\begin{array}{c}0.06 \\
(1.15)\end{array}$ & $\begin{array}{c}-0.02 \\
(-0.35)\end{array}$ & $\begin{array}{c}0.03 \\
(0.53)\end{array}$ & $\begin{array}{c}0.02 \\
(0.70)\end{array}$ & $\begin{array}{c}-0.04 \\
(-1.10)\end{array}$ & $\begin{array}{l}0.07 * \\
(1.84)\end{array}$ \\
\hline
\end{tabular}


Panels B reports the four-factor results for our trading strategy implemented with portfolios based on analyst coverage. The alphas are statistically significant for 5 (2) countries when the trading strategy is implemented with weekly (monthly) returns. Using weekly returns the alphas are significant for Canada, France, Germany, Italy and the U.K. Using monthly returns the strategy only produces significant abnormal returns in Germany and Italy.

\subsection{Transaction Costs}

This section discusses the role of transaction costs in the implementation of the trading strategy. Although we find that our trading strategy produces statistically significant abnormal returns in several countries, an important concern is that transaction costs may prevent the exploitation of these abnormal returns in practice. In particular, the implementation of the trading strategy requires an investor to frequently buy and sell a portfolio of small stocks, which may substantially decrease the realized abnormal return after trading costs.

The main problem when assessing the real-world net profitability of our trading strategy is that comprehensive real-time transaction cost data for all countries in our sample is not available to us. Also the availability of bid-ask spread data from Thomson Reuters Datastream, which could be used as an approximation for transaction costs, is limited for most countries in our sample. Alternatively, one could use transaction cost estimates from academic literature, which attempts to estimate real-world transaction costs based on econometric models or with proprietary transaction data from institutional investors. However transaction cost estimates from the academic literature are subject to considerable variability across different studies. For example, Keim and Madhavan (1997) study order level data for institutional traders and report average one-way trade costs for small firms of $1.92 \%$. More recently, Frazzini, Israel and Moskowitz (2015) study proprietary transaction cost data of a large arbitrageur. The authors argue that the real-world transaction costs of a large arbitrageur are considerable smaller compared to estimates in previous studies and report average small firm transaction costs of approximately 30 basis points (bps) for the period from 1998 to 2011.

Due to these issues, we do not assume a particular cost function but instead investigate how the abnormal returns vary with different levels of transaction costs. Specifically, we calculate abnormal returns generated by the trading strategy for one-way transaction costs between 0 and 100 bps. This way we effectively estimate the range of transaction costs for which the trading strategy is able to produce significant abnormal returns net of costs. This approach also yields an approximate upper bound for the costs for which the strategy still produces a significantly positive abnormal return.

We proceed in three steps. First, we calculate the one-way turnover in every week (month) necessary to implement our trading strategy. Let $w_{i, t}^{\text {old }}$ denotes the weight of each stock $\mathrm{j}$ at the end the previous period before rebalancing let $w_{i, t}^{\text {new }}$ denote the rebalanced weight at the beginning of the period. Then the one-sided turnover is calculated as

$$
\text { turnover }_{t}=\sum_{j=1}^{N}\left|w_{j, t}^{\text {new }}-w_{j, t}^{\text {old }}\right| .
$$

We find that the average turnover required to implement the trading strategy is considerable and ranges from $43 \%$ in the United States to 55\% in Germany if the strategy is implemented with size sorted portfolios. (Note 24) Thus, an investor, who attempts to replicate our trading strategy, would have to trade on average about $50 \%$ of his portfolio per week (or month). The high turnover is due to the requirement to buy or sell the entire portfolio frequently according to the forecast and due to rebalancing requirements. (Note 25)

Second, we use the turnover to calculate strategy $y_{t}^{t c}$, the strategy's net return after costs, by subtracting the turnover multiplied with the hypothetical costs $\mathrm{c}=0,10, \ldots, 100 \mathrm{bps}$, from the raw returns

$$
\text { strategy } y_{t}^{t c}=\text { strategy }_{t}-c \times \text { turnover }_{t} .
$$

Third, we estimate the abnormal return of the strategy by adjusting the net returns of the trading strategy for risk using the four-factor model

$$
\text { strategy } y_{t}^{t c}-R_{f, t}=a+b\left(M K T_{t}-R_{f, t}\right)+c S M B_{t}+d H M L_{t}+e W M L_{t}+\varepsilon_{t} .
$$

Table 7 shows the corresponding four-factor alphas and t-statistics as a function of transaction costs. The results show that the positive alphas quickly deteriorate as transaction costs increase. This is especially the case when the trading strategy is implemented with weekly returns. Specifically, the weekly alphas in all countries become insignificant as soon as the one-way transaction costs are above $10 \mathrm{bps}$. This finding holds for the portfolios based on size and analyst coverage. Hence, the strategy is clearly not profitable when implemented on a weekly basis due to the high trading costs. 
Table 7. Trading strategy alpha after transaction costs

This table presents abnormal returns and t-statistics of the trading strategy described in the text after transaction costs. Abnormal returns are calculated with the Carhart (1997) four-factor model. The sample period is 01/1990 - 12/2011 Micro caps, defined as firms with a market capitalization below the $20 \%$ NYSE quintile are excluded. The trading strategy invests in a portfolio of stocks stocks with high information frictions if the expected return is positive and holds cash, else. Standard errors are computed using the Newey and West (1987) procedure. *, ** and *** denote statistical significance at the $10 \%, 5 \%$, and $1 \%$ level, respectively.

Panel A: Size portfolios

\begin{tabular}{|c|c|c|c|c|c|c|c|c|c|c|c|}
\hline $\begin{array}{l}\text { Trading } \\
\text { cost } \\
\text { (bps) }\end{array}$ & $\mathbf{0}$ & 10 & 20 & 30 & 40 & 50 & 60 & 70 & 80 & 90 & 100 \\
\hline \multicolumn{12}{|c|}{ Panel A: Size portfolios } \\
\hline & \multicolumn{11}{|c|}{ Weekly returns } \\
\hline CAN & $\begin{array}{l}0.10 * * \\
(2.07)\end{array}$ & $\begin{array}{c}0.05 \\
(1.05)\end{array}$ & $\begin{array}{c}0.00 \\
(0.05)\end{array}$ & $\begin{array}{c}-0.05 \\
(-0.92)\end{array}$ & $\begin{array}{l}-0.09 * \\
(-1.86)\end{array}$ & $\begin{array}{c}-0.14 * * * \\
(-2.78)\end{array}$ & $\begin{array}{c}-0.19 * * * \\
(-3.67)\end{array}$ & $\begin{array}{c}-0.24 * * * \\
(-4.53)\end{array}$ & $\begin{array}{c}-0.29 * * * \\
(-5.36)\end{array}$ & $\begin{array}{c}-0.34 * * * \\
(-6.16)\end{array}$ & $\begin{array}{c}-0.39 * * * \\
(-6.93)\end{array}$ \\
\hline FRA & $\begin{array}{c}0.15^{* * *} \\
(3.15)\end{array}$ & $\begin{array}{l}0.10^{* * *} \\
(2.11)\end{array}$ & $\begin{array}{c}0.05 \\
(1.09)\end{array}$ & $\begin{array}{c}0.00 \\
(0.09)\end{array}$ & $\begin{array}{c}-0.04 \\
(-0.88)\end{array}$ & $\begin{array}{l}-0.09 * \\
(-1.82)\end{array}$ & $\begin{array}{c}-0.14 * * * \\
(-2.74)\end{array}$ & $\begin{array}{c}-0.18 * * * \\
(-3.62)\end{array}$ & $\begin{array}{c}-0.23 * * * \\
(-4.48)\end{array}$ & $\begin{array}{c}-0.28 * * * \\
(-5.30)\end{array}$ & $\begin{array}{c}-0.32 * * * \\
(-6.09)\end{array}$ \\
\hline GER & $\begin{array}{c}0.07 \\
(1.64)\end{array}$ & $\begin{array}{c}0.03 \\
(0.58)\end{array}$ & $\begin{array}{c}-0.02 \\
(-0.46)\end{array}$ & $\begin{array}{c}-0.07 \\
(-1.46)\end{array}$ & $\begin{array}{c}-0.12^{* *} \\
(-2.43)\end{array}$ & $\begin{array}{c}-0.17 * * * \\
(-3.37)\end{array}$ & $\begin{array}{c}-0.21 * * * \\
(-4.28)\end{array}$ & $\begin{array}{c}-0.26 * * * \\
(-5.15)\end{array}$ & $\begin{array}{c}-0.31 * * * \\
(-5.99)\end{array}$ & $\begin{array}{c}-0.36 * * * \\
(-6.80)\end{array}$ & $\begin{array}{c}-0.41 * * * \\
(-7.57)\end{array}$ \\
\hline ITA & $\begin{array}{c}0.08 \\
(1.26)\end{array}$ & $\begin{array}{c}0.03 \\
(0.45)\end{array}$ & $\begin{array}{c}-0.02 \\
(-0.35)\end{array}$ & $\begin{array}{c}-0.07 \\
(-1.13)\end{array}$ & $\begin{array}{l}-0.12 * \\
(-1.90)\end{array}$ & $\begin{array}{c}-0.17 * * * \\
(-2.64)\end{array}$ & $\begin{array}{c}-0.22 * * * \\
(-3.37)\end{array}$ & $\begin{array}{c}-0.27 * * * \\
(-4.08)\end{array}$ & $\begin{array}{c}-0.33 * * * \\
(-4.77)\end{array}$ & $\begin{array}{c}-0.38 * * * \\
(-5.45)\end{array}$ & $\begin{array}{c}-0.43 * * * \\
(-6.10)\end{array}$ \\
\hline JPN & $\begin{array}{l}0.11 * * \\
(2.34)\end{array}$ & $\begin{array}{c}0.06 \\
(1.22)\end{array}$ & $\begin{array}{c}0.01 \\
(0.13)\end{array}$ & $\begin{array}{c}-0.05 \\
(-0.94)\end{array}$ & $\begin{array}{c}-0.10^{* *} \\
(-1.97)\end{array}$ & $\begin{array}{c}-0.15^{* * *} \\
(-2.98)\end{array}$ & $\begin{array}{c}-0.21 \text { *** } \\
(-3.95)\end{array}$ & $\begin{array}{c}-0.26 * * * \\
(-4.90)\end{array}$ & $\begin{array}{c}-0.31 * * * \\
(-5.81)\end{array}$ & $\begin{array}{c}-0.37 * * * \\
(-6.70)\end{array}$ & $\begin{array}{c}-0.42 * * * \\
(-7.55)\end{array}$ \\
\hline UK & $\begin{array}{c}0.15^{* * * *} \\
(2.99)\end{array}$ & $\begin{array}{l}0.10^{* * *} \\
(1.97)\end{array}$ & $\begin{array}{c}0.05 \\
(0.97)\end{array}$ & $\begin{array}{c}0.00 \\
(0.00)\end{array}$ & $\begin{array}{c}-0.05 \\
(-0.94)\end{array}$ & $\begin{array}{l}-0.10^{*} \\
(-1.86)\end{array}$ & $\begin{array}{c}-0.15 * * * \\
(-2.75)\end{array}$ & $\begin{array}{c}-0.20 * * * \\
(-3.61)\end{array}$ & $\begin{array}{c}-0.25 * * * \\
(-4.44)\end{array}$ & $\begin{array}{c}-0.30 * * * \\
(-5.24)\end{array}$ & $\begin{array}{c}-0.35 * * * \\
(-6.01)\end{array}$ \\
\hline US & $\begin{array}{c}0.04 \\
(0.77)\end{array}$ & $\begin{array}{c}0.01 \\
(0.15)\end{array}$ & $\begin{array}{c}-0.03 \\
(-0.46)\end{array}$ & $\begin{array}{c}-0.06 \\
(-1.06)\end{array}$ & $\begin{array}{l}-0.10^{*} \\
(-1.65)\end{array}$ & $\begin{array}{c}-0.13^{* *} \\
(-2.23)\end{array}$ & $\begin{array}{c}-0.17 * * * \\
(-2.79)\end{array}$ & $\begin{array}{c}-0.21 * * * \\
(-3.34)\end{array}$ & $\begin{array}{c}-0.24 * * * \\
(-3.88)\end{array}$ & $\begin{array}{c}-0.28 * * * \\
(-4.40)\end{array}$ & $\begin{array}{c}-0.31 * * * \\
(-4.91)\end{array}$ \\
\hline & \multicolumn{11}{|c|}{ Monthly returns } \\
\hline CAN & $\begin{array}{c}0.28 \\
(1.11)\end{array}$ & $\begin{array}{c}0.24 \\
(0.92)\end{array}$ & $\begin{array}{c}0.19 \\
(0.74)\end{array}$ & $\begin{array}{c}0.14 \\
(0.55)\end{array}$ & $\begin{array}{c}0.09 \\
(0.36)\end{array}$ & $\begin{array}{c}0.05 \\
(0.18)\end{array}$ & $\begin{array}{c}0.00 \\
(-0.01)\end{array}$ & $\begin{array}{c}-0.05 \\
(-0.19)\end{array}$ & $\begin{array}{c}-0.10 \\
(-0.37)\end{array}$ & $\begin{array}{c}-0.14 \\
(-0.56)\end{array}$ & $\begin{array}{c}-0.19 \\
(-0.74)\end{array}$ \\
\hline FRA & $\begin{array}{c}0.43 * * \\
(2.18)\end{array}$ & $\begin{array}{l}0.38^{*} \\
(1.90)\end{array}$ & $\begin{array}{c}0.32 \\
(1.62)\end{array}$ & $\begin{array}{c}0.27 \\
(1.34)\end{array}$ & $\begin{array}{c}0.21 \\
(1.07)\end{array}$ & $\begin{array}{c}0.16 \\
(0.79)\end{array}$ & $\begin{array}{c}0.11 \\
(0.52)\end{array}$ & $\begin{array}{c}0.05 \\
(0.25)\end{array}$ & $\begin{array}{c}0.00 \\
(-0.02)\end{array}$ & $\begin{array}{c}-0.06 \\
(-0.28)\end{array}$ & $\begin{array}{c}-0.11 \\
(-0.54)\end{array}$ \\
\hline GER & $\begin{array}{l}0.33^{*} \\
(1.67)\end{array}$ & $\begin{array}{c}0.28 \\
(1.40)\end{array}$ & $\begin{array}{c}0.23 \\
(1.13)\end{array}$ & $\begin{array}{c}0.17 \\
(0.86)\end{array}$ & $\begin{array}{c}0.12 \\
(0.59)\end{array}$ & $\begin{array}{c}0.06 \\
(0.32)\end{array}$ & $\begin{array}{c}0.01 \\
(0.05)\end{array}$ & $\begin{array}{c}-0.04 \\
(-0.22)\end{array}$ & $\begin{array}{c}-0.10 \\
(-0.50)\end{array}$ & $\begin{array}{l}-0.15 \\
(-0.77)\end{array}$ & $\begin{array}{c}-0.21 \\
(-1.04)\end{array}$ \\
\hline ITA & $\begin{array}{c}0.30 \\
(1.17)\end{array}$ & $\begin{array}{c}0.25 \\
(0.99)\end{array}$ & $\begin{array}{c}0.21 \\
(0.80)\end{array}$ & $\begin{array}{c}0.16 \\
(0.62)\end{array}$ & $\begin{array}{c}0.11 \\
(0.43)\end{array}$ & $\begin{array}{c}0.06 \\
(0.25)\end{array}$ & $\begin{array}{c}0.02 \\
(0.07)\end{array}$ & $\begin{array}{c}-0.03 \\
(-0.11)\end{array}$ & $\begin{array}{c}-0.08 \\
(-0.29)\end{array}$ & $\begin{array}{c}-0.12 \\
(-0.47)\end{array}$ & $\begin{array}{c}-0.17 \\
(-0.64)\end{array}$ \\
\hline JPN & $\begin{array}{c}0.24 \\
(1.16)\end{array}$ & $\begin{array}{c}0.19 \\
(0.92)\end{array}$ & $\begin{array}{c}0.14 \\
(0.68)\end{array}$ & $\begin{array}{c}0.09 \\
(0.44)\end{array}$ & $\begin{array}{c}0.04 \\
(0.21)\end{array}$ & $\begin{array}{c}-0.01 \\
(-0.02)\end{array}$ & $\begin{array}{c}-0.05 \\
(-0.25)\end{array}$ & $\begin{array}{c}-0.10 \\
(-0.48)\end{array}$ & $\begin{array}{c}-0.15 \\
(-0.70)\end{array}$ & $\begin{array}{c}-0.20 \\
(-0.92)\end{array}$ & $\begin{array}{c}-0.25 \\
(-1.14)\end{array}$ \\
\hline UK & $\begin{array}{c}0.62 * * * \\
(2.82)\end{array}$ & $\begin{array}{c}0.56 * * \\
(2.57)\end{array}$ & $\begin{array}{c}0.51 * * \\
(2.31)\end{array}$ & $\begin{array}{c}0.46^{* * *} \\
(2.06)\end{array}$ & $\begin{array}{l}0.40^{*} \\
(1.81)\end{array}$ & $\begin{array}{c}0.35 \\
(1.56)\end{array}$ & $\begin{array}{c}0.30 \\
(1.32)\end{array}$ & $\begin{array}{c}0.24 \\
(1.07)\end{array}$ & $\begin{array}{c}0.19 \\
(0.83)\end{array}$ & $\begin{array}{c}0.13 \\
(0.59)\end{array}$ & $\begin{array}{c}0.08 \\
(0.36)\end{array}$ \\
\hline US & $\begin{array}{l}0.38^{*} \\
(1.67) \\
\end{array}$ & $\begin{array}{c}0.34 \\
(1.47) \\
\end{array}$ & $\begin{array}{c}0.30 \\
(1.28) \\
\end{array}$ & $\begin{array}{c}0.25 \\
(1.09) \\
\end{array}$ & $\begin{array}{c}0.21 \\
(0.89)\end{array}$ & $\begin{array}{c}0.16 \\
(0.70) \\
\end{array}$ & $\begin{array}{c}0.12 \\
(0.51)\end{array}$ & $\begin{array}{c}0.07 \\
(0.31) \\
\end{array}$ & $\begin{array}{c}0.03 \\
(0.12) \\
\end{array}$ & $\begin{array}{c}-0.02 \\
(-0.07) \\
\end{array}$ & $\begin{array}{c}-0.06 \\
(-0.27) \\
\end{array}$ \\
\hline
\end{tabular}

Panel B: Analyst portfolios

\begin{tabular}{|c|c|c|c|c|c|c|c|c|c|c|c|}
\hline $\begin{array}{l}\text { Trading } \\
\text { cost } \\
\text { (bps) }\end{array}$ & 0 & 10 & 20 & 30 & 40 & 50 & 60 & 70 & 80 & 90 & 100 \\
\hline Panel B: & & & & & & & & & & & \\
\hline
\end{tabular}

Weekly returns

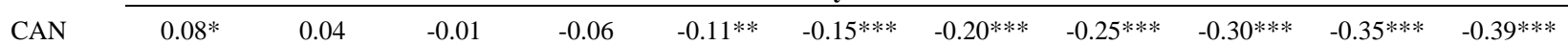




\begin{tabular}{|c|c|c|c|c|c|c|c|c|c|c|c|}
\hline & (1.67) & $(0.72)$ & $(-0.21)$ & $(-1.12)$ & $(-2.00)$ & $(-2.85)$ & $(-3.68)$ & $(-4.47)$ & $(-5.25)$ & $(-5.99)$ & $(-6.71)$ \\
\hline FRA & $\begin{array}{c}0.14 * * * \\
(3.18)\end{array}$ & $\begin{array}{l}0.09^{* *} \\
(2.15)\end{array}$ & $\begin{array}{c}0.05 \\
(1.13)\end{array}$ & $\begin{array}{c}0.01 \\
(0.15)\end{array}$ & $\begin{array}{l}-0.04 \\
(-0.82)\end{array}$ & $\begin{array}{l}-0.08 * \\
(-1.75)\end{array}$ & $\begin{array}{c}-0.13 * * * \\
(-2.65)\end{array}$ & $\begin{array}{c}-0.17 * * * \\
(-3.52)\end{array}$ & $\begin{array}{c}-0.21 * * * \\
(-4.36)\end{array}$ & $\begin{array}{c}-0.26 * * * \\
(-5.17)\end{array}$ & $\begin{array}{c}-0.30 * * * \\
(-5.95)\end{array}$ \\
\hline GER & $\begin{array}{c}0.11^{* * *} \\
(2.58)\end{array}$ & $\begin{array}{c}0.06 \\
(1.49)\end{array}$ & $\begin{array}{c}0.02 \\
(0.43)\end{array}$ & $\begin{array}{c}-0.03 \\
(-0.60)\end{array}$ & $\begin{array}{c}-0.07 \\
(-1.61)\end{array}$ & $\begin{array}{c}-0.12^{* * *} \\
(-2.58)\end{array}$ & $\begin{array}{c}-0.16^{* * * *} \\
(-3.52)\end{array}$ & $\begin{array}{c}-0.21 * * * \\
(-4.43)\end{array}$ & $\begin{array}{c}-0.25 * * * \\
(-5.31)\end{array}$ & $\begin{array}{c}-0.30 * * * \\
(-6.14)\end{array}$ & $\begin{array}{c}-0.34 * * * \\
(-6.95)\end{array}$ \\
\hline ITA & $\begin{array}{c}0.10^{* * *} \\
(2.07)\end{array}$ & $\begin{array}{c}0.06 \\
(1.08)\end{array}$ & $\begin{array}{c}0.01 \\
(0.12)\end{array}$ & $\begin{array}{c}-0.04 \\
(-0.81)\end{array}$ & $\begin{array}{l}-0.09^{*} \\
(-1.71)\end{array}$ & $\begin{array}{l}-0.14 * * \\
(-2.58)\end{array}$ & $\begin{array}{c}-0.19 * * * \\
(-3.42)\end{array}$ & $\begin{array}{c}-0.24 * * * \\
(-4.22)\end{array}$ & $\begin{array}{c}-0.29 * * * \\
(-4.99)\end{array}$ & $\begin{array}{c}-0.34 * * * \\
(-5.73)\end{array}$ & $\begin{array}{c}-0.39 * * * \\
(-6.44)\end{array}$ \\
\hline JPN & $\begin{array}{c}0.05 \\
(1.19)\end{array}$ & $\begin{array}{c}0.00 \\
(0.08)\end{array}$ & $\begin{array}{c}-0.04 \\
(-0.99)\end{array}$ & $\begin{array}{c}-0.08 * * \\
(-2.01)\end{array}$ & $\begin{array}{c}-0.12 * * * \\
(-2.98)\end{array}$ & $\begin{array}{c}-0.17 * * * \\
(-3.91)\end{array}$ & $\begin{array}{c}-0.21 * * * \\
(-4.79)\end{array}$ & $\begin{array}{c}-0.25 * * * \\
(-5.63)\end{array}$ & $\begin{array}{c}-0.29 * * * \\
(-6.42)\end{array}$ & $\begin{array}{c}-0.33 * * * \\
(-7.16)\end{array}$ & $\begin{array}{c}-0.38 * * * \\
(-7.86)\end{array}$ \\
\hline UK & $\begin{array}{l}0.10^{* * *} \\
(2.01)\end{array}$ & $\begin{array}{c}0.05 \\
(1.04)\end{array}$ & $\begin{array}{c}0.01 \\
(0.11)\end{array}$ & $\begin{array}{c}-0.04 \\
(-0.79)\end{array}$ & $\begin{array}{l}-0.09 \\
(-1.65)\end{array}$ & $\begin{array}{l}-0.13^{* *} \\
(-2.47)\end{array}$ & $\begin{array}{c}-0.18 * * * \\
(-3.26)\end{array}$ & $\begin{array}{c}-0.23 * * * \\
(-4.01)\end{array}$ & $\begin{array}{c}-0.28 * * * \\
(-4.73)\end{array}$ & $\begin{array}{c}-0.32 * * * \\
(-5.42)\end{array}$ & $\begin{array}{c}-0.37 * * * \\
(-6.08)\end{array}$ \\
\hline US & $\begin{array}{c}-0.01 \\
(-0.24)\end{array}$ & $\begin{array}{c}-0.03 \\
(-0.99)\end{array}$ & $\begin{array}{l}-0.05^{*} \\
(-1.72)\end{array}$ & $\begin{array}{c}-0.08 * * \\
(-2.43)\end{array}$ & $\begin{array}{c}-0.10 * * * \\
(-3.12)\end{array}$ & $\begin{array}{c}-0.12 * * * \\
(-3.78)\end{array}$ & $\begin{array}{c}-0.15^{* * * *} \\
(-4.42)\end{array}$ & $\begin{array}{c}-0.17 * * * \\
(-5.03)\end{array}$ & $\begin{array}{c}-0.19 * * * \\
(-5.62)\end{array}$ & $\begin{array}{c}-0.21 * * * \\
(-6.17)\end{array}$ & $\begin{array}{c}-0.24 * * * \\
(-6.70)\end{array}$ \\
\hline
\end{tabular}

\begin{tabular}{|c|c|c|c|c|c|c|c|c|c|c|c|}
\hline \multirow[b]{2}{*}{ CAN } & \multicolumn{11}{|c|}{ Monthly returns } \\
\hline & $\begin{array}{c}0.39 \\
(1.56)\end{array}$ & $\begin{array}{c}0.34 \\
(1.35)\end{array}$ & $\begin{array}{c}0.29 \\
(1.14)\end{array}$ & $\begin{array}{c}0.24 \\
(0.93)\end{array}$ & $\begin{array}{c}0.18 \\
(0.72)\end{array}$ & $\begin{array}{c}0.13 \\
(0.51)\end{array}$ & $\begin{array}{c}0.08 \\
(0.31)\end{array}$ & $\begin{array}{c}0.03 \\
(0.10)\end{array}$ & $\begin{array}{c}-0.03 \\
(-0.10)\end{array}$ & $\begin{array}{c}-0.08 \\
(-0.31)\end{array}$ & $\begin{array}{c}-0.13 \\
(-0.51)\end{array}$ \\
\hline FRA & $\begin{array}{c}0.21 \\
(1.02)\end{array}$ & $\begin{array}{c}0.16 \\
(0.75)\end{array}$ & $\begin{array}{c}0.10 \\
(0.49)\end{array}$ & $\begin{array}{c}0.05 \\
(0.22)\end{array}$ & $\begin{array}{c}-0.01 \\
(-0.04)\end{array}$ & $\begin{array}{c}-0.06 \\
(-0.30)\end{array}$ & $\begin{array}{c}-0.12 \\
(-0.55)\end{array}$ & $\begin{array}{c}-0.17 \\
(-0.80)\end{array}$ & $\begin{array}{c}-0.23 \\
(-1.05)\end{array}$ & $\begin{array}{c}-0.28 \\
(-1.29)\end{array}$ & $\begin{array}{c}-0.34 \\
(-1.53)\end{array}$ \\
\hline GER & $\begin{array}{c}0.46^{* *} \\
(2.40)\end{array}$ & $\begin{array}{c}0.41 * * \\
(2.13)\end{array}$ & $\begin{array}{l}0.36^{*} \\
(1.85)\end{array}$ & $\begin{array}{c}0.30 \\
(1.58)\end{array}$ & $\begin{array}{c}0.25 \\
(1.30)\end{array}$ & $\begin{array}{c}0.20 \\
(1.03)\end{array}$ & $\begin{array}{c}0.15 \\
(0.75)\end{array}$ & $\begin{array}{c}0.09 \\
(0.48)\end{array}$ & $\begin{array}{c}0.04 \\
(0.21)\end{array}$ & $\begin{array}{c}-0.01 \\
(-0.06)\end{array}$ & $\begin{array}{c}-0.06 \\
(-0.33)\end{array}$ \\
\hline ITA & $\begin{array}{l}0.41^{*} \\
(1.68)\end{array}$ & $\begin{array}{c}0.37 \\
(1.50)\end{array}$ & $\begin{array}{c}0.32 \\
(1.31)\end{array}$ & $\begin{array}{c}0.28 \\
(1.13)\end{array}$ & $\begin{array}{c}0.23 \\
(0.95)\end{array}$ & $\begin{array}{c}0.19 \\
(0.77)\end{array}$ & $\begin{array}{c}0.15 \\
(0.59)\end{array}$ & $\begin{array}{c}0.10 \\
(0.41)\end{array}$ & $\begin{array}{c}0.06 \\
(0.23)\end{array}$ & $\begin{array}{c}0.01 \\
(0.05)\end{array}$ & $\begin{array}{c}-0.03 \\
(-0.12)\end{array}$ \\
\hline JPN & $\begin{array}{c}-0.04 \\
(-0.31)\end{array}$ & $\begin{array}{c}-0.05 \\
(-0.42)\end{array}$ & $\begin{array}{c}-0.06 \\
(-0.53)\end{array}$ & $\begin{array}{c}-0.08 \\
(-0.64)\end{array}$ & $\begin{array}{c}-0.09 \\
(-0.75)\end{array}$ & $\begin{array}{c}-0.10 \\
(-0.85)\end{array}$ & $\begin{array}{c}-0.11 \\
(-0.96)\end{array}$ & $\begin{array}{c}-0.13 \\
(-1.06)\end{array}$ & $\begin{array}{c}-0.14 \\
(-1.16)\end{array}$ & $\begin{array}{c}-0.15 \\
(-1.26)\end{array}$ & $\begin{array}{c}-0.17 \\
(-1.36)\end{array}$ \\
\hline UK & $\begin{array}{c}0.36 \\
(1.49)\end{array}$ & $\begin{array}{c}0.32 \\
(1.30)\end{array}$ & $\begin{array}{c}0.27 \\
(1.10)\end{array}$ & $\begin{array}{c}0.22 \\
(0.90)\end{array}$ & $\begin{array}{c}0.17 \\
(0.71)\end{array}$ & $\begin{array}{c}0.13 \\
(0.51)\end{array}$ & $\begin{array}{c}0.08 \\
(0.32)\end{array}$ & $\begin{array}{c}0.03 \\
(0.13)\end{array}$ & $\begin{array}{l}-0.02 \\
(-0.07)\end{array}$ & $\begin{array}{c}-0.06 \\
(-0.26)\end{array}$ & $\begin{array}{c}-0.11 \\
(-0.45)\end{array}$ \\
\hline US & $\begin{array}{c}-0.03 \\
(-0.16)\end{array}$ & $\begin{array}{c}-0.06 \\
(-0.39)\end{array}$ & $\begin{array}{c}-0.10 \\
(-0.62)\end{array}$ & $\begin{array}{c}-0.14 \\
(-0.84)\end{array}$ & $\begin{array}{c}-0.18 \\
(-1.07)\end{array}$ & $\begin{array}{c}-0.21 \\
(-1.29)\end{array}$ & $\begin{array}{c}-0.25 \\
(-1.51)\end{array}$ & $\begin{array}{l}-0.29 * \\
(-1.73)\end{array}$ & $\begin{array}{l}-0.33^{*} \\
(-1.94)\end{array}$ & $\begin{array}{c}-0.36^{* *} \\
(-2.16) \\
\end{array}$ & $\begin{array}{c}-0.40^{* *} \\
(-2.37)\end{array}$ \\
\hline
\end{tabular}

A similar picture emerges when the trading strategy is implemented with monthly returns. The alphas quickly decline with transaction costs and mainly become insignificant for transaction costs larger than $10 \mathrm{bps}$. However, there is one exception to this finding. The strategy based on small firms in the United Kingdom produces a significantly positive abnormal return up to 40 bps trading costs. Thus, a marginal investor as studied in Frazzini, Israel and Moskowitz (2015), who has transaction costs of only $30 \mathrm{bps}$, could potentially make a profit from implementing our strategy in the United Kingdom. However, the abnormal return is probably not realizable for an average institutional investor.

Overall, our results show that a simple market timing strategy based on lead-lag relationships produces significant abnormal returns across multiple countries. However, the alphas quickly decline considering the high trading volume and transaction costs of the trading strategy. Hence, our results support the arguments in Mech (1993) and Knez and Ready (1996) who find that lead-lag relationships are probably not exploitable in practice. This result also explains why lead-lag effects still exist and have not been arbitraged away since their discovery in the early 1990s. We expect that empirical lead-lag relationships will continue to exist in the future.

\section{Conclusion}

This paper re-examines empirical lead-lag relationships based on firm size (Lo and MacKinlay (1999)), analyst coverage (Brennan, Chordia, and Swaminathan (1993)) and institutional ownership (Badrinath, Kale and Noe (1995)) across seven major developed markets. We find that lead-lag relationships according to firm size and analyst coverage continue to exist in a majority of countries. We find less evidence for the existence of lead-lag relationships in portfolios sorted by institutional ownership. These results are stable in in-sample and out-of-sample tests and in various robustness checks.

Based on these findings, we investigate whether the return predictability due to lead-lag relationships could be exploited by a real-world arbitrageur. We develop a simple trading strategy that forecasts the returns of small stocks and stocks with low analyst coverage with lagged returns of large stocks and stocks with high analyst coverage, respectively. This trading strategy is able to produce significant abnormal returns before costs according to the 
Carhart (1997) four-factor model in several countries. However, the implementation of the trading strategy requires substantial trading activity. Taking transaction costs into account, the abnormal returns quickly decline and become insignificant for one-way trading costs above $40 \mathrm{bps}$. We conclude that trading impediments are the main reason for the continued existence of lead-lag relationships. If an investor wants to use the findings of our study it's important to keep the transaction costs for trading activity below the 40 bps line of advantage.

\section{Acknowledgements}

We thank Manuel Ammann, Raphael Vial and Ulrich Carl for their helpful comments and constructive suggestions. All errors are our own.

\section{References}

Ang, A., \& Bekaert, G. (2007). Stock return predictability: Is it there?. The Review of Financial Studies, 20, 651-707. https://doi.org/10.1093/rfs/hhl021

Asparouhova, E., Bessembinder, H., \& Kalcheva, I. (2013). Noisy Prices and Inference Regarding Returns. Journal of Finance, 68, 665-714. https://doi.org/10.1111/jofi.12010

Badrinath, S.G., Kale, J.R., \& Noe, T.H. (1995). On Shephards, Sheep and the Cross-autocorrelations in Equity Returns. Review of Financial Studies, 8, 401-430. https://doi.org/10.1093/rfs/8.2.401

Boudoukh, J., Richardson, M.P., \& Whitelaw, R.F. (1994). A Tale of Three Schools: Insights on Autocorrelations of Short-Horizon Stock Returns. The Review of Financial Studies, 7, 539-573. https://doi.org/10.1093/rfs/7.3.539

Brennan, M.J., Jegadeesh, N., \& Swaminathan, B. (1993). Investment Analysis and the Adjustment of Stock Prices to Common Information. Review of Financial Studies, 6, 799-824. https://doi.org/10.1093/rfs/6.4.799

Brückner, R. (2013). Important Characteristics, Weaknesses and Errors in German Equity Data from Thomson Reuters Datastream and their Implications for the Size Effect. Working Paper, University of Mannheim.

Bushan, R. (1989). Firm characteristics and analyst following. Journal of Accounting and Economics, 11, 255-274.

Campbell, J.Y., \& Cochrane, J.H. (1999). By Force of Habit: A Consumption-Based Explanation of Aggregate Stock Market Behavior. Journal of Political Economy, 107, 205-251. https://doi.org/10.1086/250059

Campbell, J.Y., \& Thompson, S.B. (2008). Predicting Excess Stock Returns Out of Sample: Can Anything Beat the Historical Average? Review of Financial Studies, 21, 1509-1531. https://doi.org/10.1093/rfs/hhm055

Carhart, M.M. (1997). On Persistence in Mutual Fund Performance. Journal of Finance, 52, 57-82.

Chordia, T., \& Swaminathan, B. (2000). Trading Volume and Cross-Autocorrelations in Stock Returns. The Journal of Finance, 55, 913-935. https://doi.org/10.1111/0022-1082.00231

Cochrane, J.H. (2005). Asset Pricing. Princeton University Press, Princeton.

Cohen, L., \& Frazzini, A. (2008). Economic Links and Predictable Returns. Journal of Finance, 63, 1977-2011.

Cohen, L., \& Lou, D. (2012). Complicated firms. Journal of Financial Economics, 104, 383-400. https://doi.org/10.1016/j.jfineco.2011.08.006

Conrad, J., \& Kaul, G. (1988). Time-Variation in Expected Returns. Journal of Business, 61.

Conrad, J., \& Kaul, G. (1989). Mean Reversion in Short-Horizon Expected Returns. Review of Financial Studies, 2, 225-240. https://doi.org/10.1093/rfs/2.2.225

Diamond, D.W., \& Verrecchia, R.E. (1987). Constraints on short-selling and asset price adjustment to private information. Journal of Financial Economics, 18, 277-311. https://doi.org/10.1016/0304-405X(87)90042-0

Fama, E., \& French, K.R. (1989). Business Conditions and Expected Returns on Stocks and Bonds. Journal of Financial Economics, 25, 23-49. https://doi.org/10.1016/0304-405X(89)90095-0

Fama, E.F., \& French, K.R. (1993). Common Risk Factors in the Returns on Stocks and Bonds. Journal of Financial Economics, 33, 3-56. https://doi.org/10.1016/0304-405X(93)90023-5

Fama, E.F., \& French, K.R. (2008). Dissecting Anomalies. Journal of Finance, 63, 1653-1678.

Fama, E.F., \& French, K.R. (2012). Size, value, and momentum in international stock returns. Journal of Financial Economics, 105, 457-472. https://doi.org/10.1016/j.jfineco.2012.05.011

Fargher, N.L., \& Weigand, R.A. (1998). Changes in the Stock Price Reaction of Small Firms to Common Information. Journal of Financial Research, 21, 105-121. 
Ferreira, M.A., \& Santa-Clara, P. (2011). Forecasting stock market returns: The sum of the parts is more than the whole. Journal of Financial Economics, 100, 514-537. https://doi.org/10.1016/j.jfineco.2011.02.003

Frazzini, A., Israel, R., \& Moskowitz, T.J. (2015). Trading Costs of Asset Pricing Anomalies. Working Paper, University of Chicago.

Goyal, A., \& Welch, I. (2008). A Comprehensive Look at The Empirical Performance of Equity Premium Prediction. Review of Financial Studies, 21, 1455-1508. https://doi.org/10.1093/rfs/hhm014

Granger, C.W.J. (1969). Investigating Causal Relations by Econometric Models and Cross-spectral Methods. Econometrica, 37, 424-438. https://doi.org/10.2307/1912791

Greene, W.H. (2011). Econometric Analysis. Prentice Hall, New Jersey.

Griffin, J.M., Kelly, P.J., \& Nardari, F. (2010). Do Market Efficiency Measures Yield Correct Inferences? A Comparison of Developed and Emerging Markets. Review of Financial Studies, 23, 3225-3277. https://doi.org/10.1093/rfs/hhq044

Grossmann, S.J., \& Stiglitz, J.E. (1980). On the Impossibility of Informationally Efficient Markets. American Economic Review, 70, 393-408.

Hjalmarsson, E. (2010). Predicting Global Stock Returns. Journal of Financial and Quantitative Analysis, 45, 49-80. https://doi.org/10.1017/S0022109009990469

Hong, H., \& Stein, J. (2007). Disargreement and the Stock Market. Journal of Economic Perspectives, 21, 109-128.

Hong, H., \& Stein, J.C. (1999). A Unified Theory of Underreaction, Momentum Trading, and Overreaction in Asset Markets. The Journal of Finance, 54, 2143-2184. https://doi.org/10.1111/0022-1082.00184

Hou, K. (2007). Industry Information Diffusion and the Lead-lag Effect in Stock Returns. Review of Financial Studies, 27, 1113-1138. https://doi.org/10.1093/revfin/hhm003

Hou, K., \& Moskowitz, T.J. (2005). Market Frictions, Price Delay, and the Cross-Section of Expected Returns. Review of Financial Studies, 18, 981-1020. https://doi.org/10.1093/rfs/hhi023

Ince, O.S., \& Porter, R.B. (2006). Individual equity return data from thomson datastream: handle with care! Journal of Financial Research, 29, 463-479. https://doi.org/10.1111/j.1475-6803.2006.00189.x

Keim, D.B. (1999). An Analysis of Mutual Fund Design: The Case of Investing in Small-Cap Stocks. Journal of Financial Economics, 51, 173-194. https://doi.org/10.1016/S0304-405X(98)00049-X

Keim, D.B., \& Madhavan, A. (1997). Transaction costs and investment style: an inter-exchange analysis of institutional equity trades. Journal of Financial Economics, 46, 265-292. https://doi.org/10.1016/S0304-405X(97)00031-7

Knez, P.J., \& Ready, M. (1996). Estimating the Profits from Trading Strategies. Journal of Finance, 9, 1121-1163.

Korajczyk, R.A., \& Sadka, R. (2004). Are Momentum Profits Robst to Trading Costs?. Journal of Finance, 59, 1039-1082. https://doi.org/10.1111/j.1540-6261.2004.00656.x

Lesmond, D.A., Schill, M.J., \& Zhou, C. (2004). The Illusory Nature of Momentum Profits. Journal of Financial Economics, 71, 349-380. https://doi.org/10.1016/S0304-405X(03)00206-X

Lo, A.W., \& MacKinlay, A.C. (1990). When are Contrarian Profits Due to Stock Market Overreaction?. Review of Financial Studies, 3, 175-205. https://doi.org/10.1093/rfs/3.2.175

McQueen, G., Pinegar, M., \& Thorley, S. (1996). Delayed Reaction to Good News and the Cross-Autocorrelation of Portfolio Returns. Journal of Finance, 51, 889-919. https://doi.org/10.1111/j.1540-6261.1996.tb02711.x

Mech, T.S. (1993). Portfolio return autocorrelation. Journal of Financial Economics, 34, 307-344.

Merton, R.C. (1987). A Simple Model of Capital Market Equilibrium with Incomplete Information. Journal of Finance, 42, 483-510. https://doi.org/10.1111/j.1540-6261.1987.tb04565.x

Newey, W.K., \& West, K.D. (1987). A Simple, Positive Semi-Definite, Heteroskedasticity and Autocorrelation Consistent Covariance Matrix. Econometrica, 55, 703-708. https://doi.org/10.2307/1913610

Nguyen, Q.H. (2012). Geographic Momentum. Working Paper, University of Illinois.

Novy-Marx, R., \& Velikov, M. (2015). A Taxonomy of Anomalies and Their Trading Costs. Review of Financial Studies, forthcoming. 
Pastor, L., \& Stambaugh, R.F. (2009). Predictive Systems: Living with Imperfect Predictors. Journal of Finance, 64, 1583-1628. https://doi.org/10.1111/j.1540-6261.2009.01474.x

Pontiff, J., \& McLean, R.D. (2015). Does Academic Research Destroy Stock Return Predictability?. Journal of Finance, forthcoming.

Rapach, D.E., Strauss, J.K., \& Zhou, G. (2013). International Stock Return Predictability: What Is the Role of the United States? The Journal of Finance, 68, 1633-1662. https://doi.org/10.1111/jofi.12041

Rapach, D.E., \& Zhou, G. (2013). Forecasting Stock Returns. In Graham E \& Timmermann A. (Eds.), Handbook of Economic Forecasting (pp. 328-383). Amsterdam. https://doi.org/10.1016/B978-0-444-53683-9.00006-2

Saffi, P.A.C., \& Sigurdsson, K. (2010). Price Efficiency and Short Selling. Review of Financial Studies, 24, 821-852. https://doi.org/10.1093/rfs/hhq124

Schmidt, P.S., Schrimpf, A., von Arx, U., Wagner, A.F., \& Ziegler, A. (2015a). On the Construction of Common Size, Value and Momentum Factors in International Stock Markets: A Guide with Applications. Working Paper, University of Zurich.

Schmidt, P.S., Schrimpf, A., von Arx, U., Wagner, A.F., \& Ziegler, A. (2015b). Size and Momentum Profitability in International Stock Markets. Working Paper, University of Zurich.

Shleifer, A., \& Vishny, R.W. (1997). The Limits of Arbitrage. Journal of Finance, 52, 35-55.

Tse, Y. (2015). Do industries lead stock markets? A reexamination. Journal of Financial Economics, 34, 195-203. https://doi.org/10.1016/j.jempfin.2015.10.003

Van Binsbergen, J.H., \& Koijen, R.S.J. (2010). Predictive Regressions: A Present-Value Approach. Journal of Finance, 65, 1439-1471. https://doi.org/10.1111/j.1540-6261.2010.01575.x

\section{Notes}

Note 1. McLean and Pontiff (2015) revisit multiple cross-sectional return anomalies and find that the magnitude of multiple anomalies declines after their discovery. Their results suggest that investors learn from academic publications, which leads to arbitrage activity and a deterioration of these anomalies. Tse (2015) revisits the previous work of Hong, Torous and Valkanov (2007) and finds that their results are far less significant using new data.

Note 2. See Brennan, Chordia, and Swaminathan (1993), Bradrinath, Kale, and Noe (1995), McQueen, Pinegar and Thorley (1996), Fargher and Weigand (1998), Chordia and Swaminathan (2000), Hou and Moskowitz (2005), Hou (2007), Hong, Torous and Valkanov (2007), Rapach, Strauss and Zhou (2013).

Note 3. It is well known that firm coverage of Thomson Reuters Datastream is time dependent. Hence, we follow recommendation in Schmidt, Schrimpf, von Arx, Wagner, and Ziegler (2015) and Brückner (2013) and select 1990 as the start year of our sample.

Note 4. The construction of the data largely follows Ince and Porter (2006) and Schmidt, Schrimpf, von Arx, Wagner, and Ziegler (2015).

Note 5. Thomson Reuters Datastream and Worldscope constituent lists Canada: WSCOPECN, WSCN1-WSCN5, DEADCN1-DEADCN2; France: WSCOPEFR, FFRA, ALLFF, DEADFR; Germany: WSCOPEBD, FGER1-FGER2, DEADBD1-DEADBD2; Italy: WSCOPEIT, FITA, DEADIT; Japan: WSCOPEJP, FJAP, DEADJP; United Kingdom: WSCOPEUK, FBRIT, DEADUK; United States: FUSAA-FUSAG, DEADUS1-DEADUS6, WSUS1-WSUS18.

Note 6. Ince and Porter (2006) and Schmidt, Schrimpf, von Arx, Wagner, and Ziegler (2015) only use constituent lists for active and dead firms maintained by Datastream and Worldscope to construct their sample. However, as noted in Ince and Porter (2006) and in Brückner (2013), these constituent lists can be incomplete. Therefore, we additionally use the Datastream criteria search tool to identify all stocks from a specific country (status =all, market= name of country, instrument type=equity).

Note 7. For the countries that have adopted the Euro in 2002, we download the entire dataset in Euros.

Note 8. Complete list of labels: Following Ince and Porter (2006) and Griffin, Kelly and Nardari (2010) we delete all securities where the name contains the following labels: 500, BOND, DEFER, DEP, DEPY, ELKS, ETF, FUND, FD, IDX, INDEX, LP, MIPS, MITS, MITT, MPS, NIKKEI, NOTE, PERQS, PINES, PRTF, PTNS, PTSHP, QUIBS, QUIDS, RATE, RCPTS, RECEIPTS, REIT, RETUR, SCORE, SPDR, STRYPES, TOPRS, UNIT, UNT, UTS, WTS, 
XXXXX, YIELD, YLD, EXPIRED, EXPD EXPIRY, EXPY, DUPLICATE, DUPL, DUP, DUPE, DULP, DUPLI, 1000DUPL, XSQ, XET, ADR, GDR, PREFERRED, PF, PFD, PREF, 'PF', WARRANT, WARRANTS, WTS, WTS2, WARRT, DEB, DB, DCB, DEBT, DEBENTURES, DEBENTURE, RLST IT, INVESTMENT TRUST, INV TST, UNIT TRUST, UNT TST, TRUST UNITS, TST UNITS, TRUST UNIT, TST UNIT. In addition, we manually check the names of all excluded securities for false positives. For instance, we could accidentally exclude the stock of Pfizer due to the search term 'PF', which is commonly used by Thomson Reuters Datastream to tag preferred stock.

Note 9. For monthly returns, if $r_{t}$ or $r_{t-1}>300 \%$ and $\left(1+r_{t}\right)\left(1+r_{t-1}\right)-1<50 \%$, we set $r_{t}$ and $r_{t-1}$ to missing. For monthly returns, if $r_{t}$ or $r_{t-1}>100 \%$ and $\left(1+r_{t}\right)\left(1+r_{t-1}\right)-1<20 \%$, we set $r_{t}$ and $r_{t-1}$ to missing. Kelly, Griffin and Nardari (2010) also use these screens.

Note 10. A variable $\mathrm{X}$ is said to Granger-cause another variable $\mathrm{Y}$, if lagged values of $\mathrm{X}$ significantly predict $\mathrm{Y}$, controlling for Y's own lagged values (Granger, 1969).

Note 11. In unreported results we also test finer portfolio sorts such as quartiles and quintiles. We find that finer sorts yield qualitatively and quantitatively similar results compared to our three portfolios based on the bottom $30 \%$, mid $40 \%$ and high $30 \%$. However, these finer sorts can decrease the number of stocks in each portfolio and the diversification across portfolios in countries, where the total number of firms is comparably small.

Note 12. Asparouhova, Bessembinder and Kalcheva (2013) extend the work of Blume and Stambaugh (1983), who show that zero-mean noise in prices leads to a positive bias in average returns. Asparouhova, Bessembinder and Kalcheva (2013) show weighting stocks by prior-month market value effectively mitigates the return bias in noisy prices.

Note 13. Following the recommendation in Greene (2011), we set the lag length for the Newey and West covariance matrix estimator to the fourth root of the number of observations.

Note 14. In context of the well-known bias-variance trade-off in statistics, pooling across multiple countries can potentially introduce bias into the parameter estimates but it also increases estimation efficiency. The pooled estimator can also be interpreted as a shrinkage-type estimator, which shrinks the parameter estimates to the average across countries.

Note 15. Note that the t-test for the first lag coefficient corresponds to the general Granger-causality test if we set the maximum number of lags to one.

Note 16 . This significantly negative $\hat{b}_{4}$ in the pooled regression using equally weighted portfolio returns is due to the negative coefficient of Canada. Excluding Canada, the pooled coefficient is negative but not significant.

Note 17. In unreported results, we repeat our Granger-causality tests extending the maximum lag length to 10 weeks. Badrinath, Kale and Noe (1995) report significantly positive coefficients between lags 8 and 10. However, we do not find any significant coefficients estimates at these higher order lags.

Note 18. Data on NYSE percentiles are obtained from Kenneth French's homepage: http://mba.tuck.dartmouth.edu/pages/faculty/ken.french/data_library.html

Note 19. Rapach and Zhou (2013) summarize the literature on out-of-sample stock return predictability.

Note 20. The previous studies of Lo and MacKinlay (1990), Brennan, Chordia, and Swaminathan (1993), Badrinath, Kale, Noe (1995), Chordia and Swaminathan (2000) and Hou (2007) are purely based on in-sample results and do not consider out-of-sample predictability.

Note 21 . We obtain qualitatively similar results when we perform the out-of-sample tests with value weighted returns.

Note 22. Campbell and Thompson (2008) demonstrate for the U.S. stock market, that already small $R_{O S}^{2}$ values around $0.5 \%$ can have substantial impact on the portfolio choice and utility of a mean variance investor.

Note 23. As before we use and expending window to estimate the predictive regressions and we use the first 5 years (01/1990-12/1994) as the initial estimation period.

Note 24 . The average turnover is qualitatively similar fort he trading strategy implemented with portfolios based on analyst coverage.

Note 25. If a stock stops trading, e.g. due to merger or bankruptcy, the holdings of that stock is invested in the remaining stocks in the sample. 